\title{
Raising Students' Cultural Awareness and Developing Their Intercultural Communicative Competence: The Case of the Greek State Primary School EFL Textbooks
}

\author{
Zoumi Iakovina $^{1} \&$ Ioannis D. Karras ${ }^{2 \& 3}$ \\ ${ }^{1}$ English language and Literature, M.Ed. in TEIL/TEFL, Kostos-Paros, 84400 Greece \\ ${ }^{2}$ Associate Professor of Applied Linguistics \& Intercultural Communication, Dept. of Foreign Languages, \\ Translation and Interpreting, Ionian University, Greece \\ ${ }^{3}$ Deputy Director, Module Coordinator \& Tutor on the TEIL/TEFL Master's Programme, Hellenic Open \\ University, Asklipios Building (1st Floor) Corfu. 49100, Greece \\ Correspondence: Zoumi Iakovina, English language and Literature, M.Ed. in TEIL/TEFL, Kostos-Paros, 84400 \\ Greece. E-mail: ziakovina@yahoo.gr
}

Received: September 23, 2021

Accepted: November 23, 2021

Online Published: December 21, 2021

doi:10.5539/ijel.v12n1p154

URL: https://doi.org/10.5539/ijel.v12n1p154

\begin{abstract}
The present study focuses on the critical evaluation of the cultural content incorporated in the 5th and 6th grade English textbooks, which are taught in the Greek state primary school. Given that we are living in the era of increasing globalization, it is deemed essential that aspects of diverse cultures should be reflected in the English textbooks, thus enabling contemporary EFL learners to master the ability to use the English language efficiently in their intercultural interactions regardless of their socio-cultural background. The research findings succinctly reveal that the vast majority of state EFL teachers in Greece are fervent proponents of an intercultural approach in their teaching practices. However, they are not reliant on the prescribed textbooks under scrutiny for promoting the intercultural dimension in their educational methodology, since their cultural input is assessed as deficient and inadequate for dynamic intercultural instruction.
\end{abstract}

Keywords: language and culture, intercultural awareness, intercultural communicative competence, intercultural education, intercultural values, textbook evaluation

\section{Introduction}

It is an established reality that the modern world is regarded as a 'global village' (Kramsch, 1987) composed of increasingly heterogeneous societies with members featuring diverse cultural attributes, lifestyles, beliefs, values, attitudes and behavioral conventions. More specifically, the ongoing merging of cultures has radically altered the homogeneous, monolingual and monocultural societal profile into a multilingual and multicultural one, which is ascribed to the advent of globalization and the massive influx/inflow of immigrants and refugees (Gogonas, 2010). In Greece, this situation is presently mirrored in the school population, as students of diverse linguistic and national or ethnic background co-exist carrying different cultural 'baggage' that, in essence, reflects their cultural identity traits (Lytra, 2008).

In light of these developments, a shift towards an intercultural stance is discernible in the Greek EFL educational context as a derivative of the dramatic societal changes and the impact of multiculturalism delineated. In effect, the last two versions of the Greek National EFL Curriculum, namely the CTCF (Note 1) (2003-2015) and the IFLC (Note 2) (2016), ratify an intercultural outlook in ELT (Anastasiadou, 2015) and they emphatically stress the significance of raising the young learners' awareness of cultural and linguistic pluralism. In this sense, they both advocate a transnational perspective that breeds a spirit of embracement of multicultural identity and promotes global citizenship (Karras, 2021; Penderi, 2018).

Accordingly, this research seeks to establish the position of 'culture teaching' as implemented through the English language medium in the fifth and sixth grade of a six-grade system in a Greek primary school context. It is expected that light will be shed on the teachers' intercultural philosophy when it comes to creating the students' cultural awareness (CA) and cultivating their intercultural communicative competence (ICC) skills. Most 
importantly, this article determines the degree to which the assigned English textbooks currently taught are conducive to meeting the aims of intercultural instruction, given that developing intercultural understanding and ICC aptitude are deemed crucial life skills in order to efficiently interact and live together with people from different cultural backgrounds in a single interconnected global system (Lo Bianco, Liddicoat, \& Crozet, 1999).

Securing 'culture' a rightful place or meaningfully integrating it into EFL teaching has become a primary concern for TESOL-practitioners (Nault, 2006). This assumption, however, merits further elaboration since it is not an uncommon phenomenon to neglect or ignore the cultural dimension of EFL-teaching, despite the significance attributed to it as a fundamental component of language learning. To better exemplify this claim, it should be mentioned that based on survey findings 'culture teaching' in the Greek state school remains insubstantial and sporadic (Tzotzou \& Kotsiou, 2015), which indicates that its application is not systematic or structured to a satisfactory level. The same holds true in other countries as proffered by many researchers in the field of intercultural education (Mekheimer, 2011; Raigon-Rodriguez, 2018; Reimann, 2009).

Within this line of thought, it is reported that the cultural content in EFL textbooks is of limited range given that the cultural elements portrayed in the teaching materials (TM) are almost invariably of debatable amplitude and depth. In other words, 'culture' instruction is rather not purposefully implemented. Instead, it is often treated as a by-product and dealt with incidentally (Karras, 2021, p. 178), being confined to mere transmission of information (Kramsch, 1993). As a result, cultural diversity is not sufficiently emphasized nor are intercultural values promoted (Ajideh \& Panahi, 2016; Kailola, 2016). Being mindful of these propositions, the researcher was intrigued to scrutinize the extent to which the above illustrated status of 'culture teaching' is still valid in the contemporary Greek educational reality.

After the subsequent Literature Review, the methodological framework adopted in this study is justified and analyzed. The presentation and discussion of the research results follow so as to foreground the current situation with regard to the intercultural educational and teaching practices within the aforementioned primary school context.

\section{Literature Review}

\subsection{Defining 'Culture’and Its Interrelationship with Language}

Admittedly, the endeavor to define the nature of 'culture' has proven a rather convoluted, notoriously difficult and obscure task to accomplish (Byram, 1989; Kramsch, 2002), for 'culture' is one of the most complicated words in the English language (Williams, 1983, p. 87). In this regard, proclaiming 'culture' as a process of perceiving, interpreting and feeling the world (Robinson, 1985) or a way of coping with the world and defining it in detail (Bradbury, n.d.), it can be argued that 'culture' can make people understand each other better (Coelho, 2015).

Introduced by Tylor $(1871$, p. 1) the term 'culture' alludes to "that complex whole which includes knowledge, ideas, art, law, morals, customs and any other capabilities and habits learned by human" as a society member. Since then, there have been a plethora of attempts to plausibly define one of the most potent and highly complicated concepts pertinent to human existence, given that 'culture' permeates all aspects of 'human' as a social being and as such it is ubiquitous in every facet of human life. In this anthropological purview, 'culture' functions as the lens through which we view the world (Davies, 2006) and 'language' forms its reflection or rudimentary ingredient. Put differently, 'language' is an expression of culture (Larzen, 2005) assuming that its use is underpinned by social and cultural values.

As Kramsch (1993, p. 177) forcefullly states "it is a truism to say that teaching a language is teaching culture", thereby meaning that FL (Note 3) instruction hardly stipulates teaching exclusively the linguistic system but it also entails teaching the cultural system. In practice, these two entities share an indivisible bond that keeps them intricately interwoven to the extent that they are considered entwined and interdependent (Alptekin, 1993; Buttjes, 1990; Robinett, 1980). Many scholars have probed into their inextricable (inter)relationship (Byram, 1988), inevitably arriving at the cliché consensus that "language is part of a 'culture' and 'culture' is part of a language" (Brown, 2000, p. 113), which arguably foregrounds the inseparability and the interpenetration of the two notions (Diaz, 2013; Zu \& Kong, 2009).

In Tomalin's (2008) rationale, 'culture' is accorded the status of the 'fifth skill' in language teaching, thus adding to the four traditional ones (i.e., reading, writing, speaking and listening) (Damen, 1987). Yet, it should not hold the role of the expendable fifth skill tacked on the teaching of the others, as it "is always in the background" ready to pinpoint the limitations of the learners' hard-won communicative competence and challenge their ability to make sense of the world around them (Kramsch, 1993, p. 1). This language-culture nexus (Liu, 2019) is 
metaphorically illustrated by comparing their bond to flesh and blood (Jiang, 2000). Summarizing, 'culture' forms part and parcel of the language learning process adding to its educational value (Byram, 1988) as they complement and enrich each other towards promoting and regulating communication.

Hence, the integration of 'culture' in EFL-teaching is regarded as apposite and necessary (Fageeh, 2011) and as such it should become the core of language classroom practices, considering that cultural awareness (CA) augments language proficiency and enhances students' overall learning experience (Vernier, Bartuzza, Giusti, \& Moral, 2008). Moreover, if language is perceived as a social practice giving insight into the political, social, religious or economic domain, then language teaching devoid of cultural-aspects is regarded as a lifeless endeavor (Sellami, 2000) utterly inconceivable not to mention practically infeasible, inaccurate and incomplete (Peck, 1998).

\subsection{Broad Categories of 'Culture' in the ELT-Context}

Against this backdrop, aspiring to explore the "intangible, all-pervasive and highly variable force" of 'culture' (Crozet \& Liddicoat, 1999, p. 116) different classifications are put forward, so as to foster better comprehension of its intricate and multifarious dimensions. It should be noted, however, that only the ones operationalized in this research are mentioned.

As depicted in the widely-known iceberg image (Hall, 1976), 'culture' can be distinguished as possessing two sides. The first is the objective cultural representation pertaining to its visible, easily discernible and tangible aspects like behaviors and products, whereas the second lurking underneath is the subjective one related to the non-visible, barely observable and intangible qualities it contains such as ideas, values, and beliefs (Robinson, 1985, 1988).

With regard to the TEFL-framework (Note 4), a differentiation exists between 'culture-specific' and 'culture-general' dimension. In this respect, the 'culture-specific' paradigm is basically linked to the target cultures and societies of the UK and the USA, which belong to the inner-circle countries (Kachru, 1985). By contrast, the 'culture-general' facet espouses a multicultural perspective to language learning and is harnessed by alternative 'post EFL era' EFL teaching paradigms to be analyzed in the following section (Sifakis, 2014).

Moreover, Cortazzi and Jin (1999) classified 'culture' representation into having source (C1), target (C2) and international orientation (C3). Analytically, $\mathrm{C} 1$ refers to the students' native culture; $\mathrm{C} 2$ is associated with the countries where the target language is spoken as a first language, whereas $\mathrm{C} 3$ pertains to various world cultures. In addition to this tripartite classification, Aliakbari (2004) added the 'neutral' or 'a-cultural' category, which features little or no particular interest in culture.

Another noteworthy distinction pertains to the Big ' $\mathrm{C}$ ' and small ' $\mathrm{c}$ ' culture-topics imparted to EFL learners (Chastain, 1988; Paige, Jorstad, Paulson, Klein, \& Colby, 1999), representing the static and dynamic features of 'culture' respectively. Specifically, Big 'C' culture covers general themes, namely literature, fine arts, history, politics, economy, education, social norms, geography, architecture and music, whereas small 'c' culture refers to daily routines, lifestyles, food, holidays, customs, values, beliefs, hobbies, gestures and body language (Chen, 2004; Lee, 2009). This categorization is analogous to the visible and invisible part of the iceberg mentioned earlier (Bocu \& Razi, 2016).

\subsection{The Challenges ELT Faces in an Increasingly Globalized World}

In view of the prevalent cultural and linguistic interconnectedness, ELT methodology and pedagogy have been impelled to face the challenges posed by the omnipresent global cultural flows on the one hand (Pennycook, 2007) and the emergence of the 'World Englishes' (Kachru, 2004) pertinent to 'English' used as an international language (EIL) or lingua franca (ELF) (Lee, 2012) on the other. This hypothesis renders the focal aims of TEFL hardly responsive to the universal dimensions of the English language. In fact, English is not exclusively associated with any single nation or group anymore (Jenkins, 2003). In this sense, it cannot be limited to particular geographical boundaries or linked to a specific target culture in a fixed monolithic sense (Baker, 2012; Bouslama \& Benaissi, 2018). Therefore, global cultural consciousness and intercultural citizenship are sought after as key outcomes of EFL methodology, which will eventually lead to shaping culturally and politically conscious citizens (Byram, 2011; Kumaravadivelu, 2008).

Aligned with these developments, ELT should pursue a transformative goal attainable through critically-oriented pedagogy, reinforced by cultural reflection and supported by TM that "prompt learners to confront some of the taken for granted cultural beliefs about the Self and the Other" (Kumaravadivelu, 2008, p. 189). Thereby, EFL needs to re-orient and enrich its firmly embraced methodological orientation by incorporating elements from TEIL, TELF, TEIC (Note 5) and TEMA (Note 6) paradigms, which afford the potential to accommodate cultural 
and linguistic diversity by embracing a 'culture-general' approach that prioritizes cross-cultural comprehensibility (Fay, 2008). In a similar vein, the latest trends in ELF-teaching have instigated a re-conceptualisation of the EFL teaching goals and approaches so as to respond to the overwhelming global demands for intercultural communication (Byram \& Wagner, 2018).

\subsection{ELT and 'Culture-Teaching'}

As crystallized from the above discussion, the development of linguistic competence, language proficiency and NS (Note 7) model behavior (Byram, 1997; Kachru \& Smith, 2008) cannot guarantee efficient intercultural communication since misunderstandings, conflicts and even communication breakdown or failure are likely to occur among interlocutors on account of cultural diversity (Fantini \& Tirmizi, 2006). Similarly, the EFL speakers' grammatical or phonological errors can be tolerated unlike cultural errors that might lead to miscommunication problems (Ahmed, Quasem, \& Pawar, 2019). Hence, not only should EFL-learners be acquainted with the 'culture' of the target language but also gain insight into their own culture and other cultures by means of the target language (Mayangsari, Nurkamto, \& Supriyadi, 2018).

However, the incorporation of 'culture teaching' in EFL entails a plethora of parameters (in)directly related with socio-political and ideological factors. This, in turn, explains why language used to be separated from 'culture' and justifies why the focus of classroom activities excluded cultural aspects, thus condemning EFL instruction to a decontextualized method of teaching bereft of cultural scope (Chaouche, 2016). In practice, even today's actual teaching practices tend to grant prominence to the linguistic dimension at the expense of the cultural one instead of treating both of them equally (Tzotzou \& Kotsiou, 2015).

\subsection{Intercultural Approach to ELT}

Taking Sercu's (2002) lead that language education should always also be intercultural education, espousing an intercultural approach in the EFL classroom practices merits being treated as top priority. Accordingly, as Van Ek (1986) points out, ELT has a twofold role, namely train learners in communication skills and contribute to their personal and social development. Following the same line of thought, Mendez-Garcia (2005) prudently remarks that intercultural familiarization arms EFL-speakers with world knowledge, acquaints them with culturally-conditioned behaviors, fosters mutual respect and tolerance towards different cultures, thus encouraging empathy towards people cross-culturally. As a consequence, apart from increasing the learners' CA and communicative competence, intercultural instruction is conducive to maximizing their insight into and acceptance of diverse social variables and cultural norms, which fosters their understanding of how intercultural communication takes place and stimulates their intellectual curiosity about target cultures (Tomalin \& Stempleski, 2013).

Based on the contention that intercultural education is a powerful agent of change towards social welfare, solidarity, openness and respect to linguistic and cultural diversity (Tzotzou, 2013), it goes without saying that the intercultural approach to EFL-teaching contributes to broadening the learners' understanding of cultural roots. Concurrently, students are enabled to recognize, appreciate, accept and efficiently communicate across cultural differences in a variety of multicultural contexts (Al-Sofi, 2018), thus contributing to shaping respectful international citizens.

As a corollary, a prime mission undertaken by EFL-practitioners is to guide learners into displaying empathy and sympathy towards people of different cultural backgrounds and assuming a positive attitude of acceptance and tolerance towards other cultural value-systems by being aware of their own culture plus other cultures (Chao, 2013; Eken, 2015). In this way, learners develop intercultural sensitivity (IS) and they can counter negative stereotypes and prejudices (Seelye, 1993) by adopting a penetrative worldview that concurrently enhances their communicative ability.

\subsection{Cultural Awareness and Intercultural Communicative Competence}

Hereby, clarifying the interrelated terms cultural awareness (CA) and intercultural communicative competence (ICC) is deemed essential. In particular, CA encompasses the qualities of awareness of one's own and others' culturally-induced behavior along with the ability to explain one's own cultural standpoint, which entail "sensitivity to the impact of culturally-induced behavior on language use and communication" (Tomalin \& Stempleski, 2013, p. 5). For Tomlinson (2001), CA signifies developing inner sense of the equality of cultures and a positive interest in how they connect or differ, whereas Byram (1997) builds on CA in his ICC-model by advancing the value of critical cultural awareness (CCA). The latter denotes the ability to critically evaluate the social and political world on the basis of explicit criteria, perspectives, practices and products in one's native culture and foreign cultures (Kreisberg, 1992). 
Moving a step forward, Byram (1997), introduced ICC as one of the recently added components of communicative competence that comprises linguistic, sociolinguistic, strategic and discourse competence (Canale \& Swain, 1980) along with social and socio-cultural competence, which were Van Ek's (1986) addition. Specifically, in Byram's (1997) ICC-model, the interconnection of linguistic, sociolinguistic, discourse and intercultural competences form the overall ICC (Ahmed et al., 2019), whereas Fantini (2000) illustrates five dimensions of the ICC-construct, namely awareness, attitudes, skills, knowledge and language proficiency, which encompass both linguistic and cultural qualities.

In light of the above, ICC is regarded as an essential skill for surviving in today's pluralist and globalized world (Liu, 2016; Sifakis, 2009). It relates to the "ability to communicate effectively and appropriately in intercultural situations based on one's intercultural knowledge, skills and attitudes" (Deardorff, 2006, p. 247). This definition embodies the essence of ICC as it spotlights its integral constituents, namely intercultural communication awareness and intercultural sensitivity (Chen \& Starosta, 2000), not failing to stress its high significance to language learning. Understandably, the acquisition of ICC comprises one of the major goals pursued in EFL since 'intercultural speakers' lacking this quality are interculturally-incompetent or fluent fools, who speak the language but do not apprehend its social and philosophical content, consequently being unaware of the cultural risks involved (Bennett, 1993).

\subsection{The Role of Textbooks in 'Culture-Teaching'}

Among their presumed roles, textbooks as teaching materials (TM) are active participants in cultural transmission within the educational and societal framework (Risager, 1991) by acting as tools that aid culture-teaching (Tzotzou \& Kotsiou, 2015). Hence, they are reckoned highly influential since they provide the basis for the cultural-content to be dealt with in the EFL-classroom (McKay, 2003) and strengthen culture-learning (Note 8), which practically boosts the attainment of ICC-skills (Paige et al., 1999) and enhances CA.

Admittedly, however, it is difficult for a textbook to address the multicultural milieu of EFL-classes considering that it constitutes the primary source of 'cultural-literacy' in many teaching situations, thus pointing out its principal role in shaping cultural attitudes (Hatoss, 2004). Therefore, it is the authors' onus to assume responsibility for the cultural depiction they convey through the textbooks (Wright, 1999), as the latter operate as ideology catalysts addressing multicultural audiences. For this reason, they are often blamed for promoting the value systems of NS-countries, overlooking or intentionally omitting an objective manifestation and dissemination of different cultural aspects and behaviors (Pennycook, 1994; Morgan, 1995).

Undeniably, textbooks are utterly influential in the process of formulating a cultural stance and cultivating CA, which makes it necessary to ensure that the cultural-input they include is not confined to facts-processing and tangible elements of cultural knowledge (Hatoss, 2004). That said, textbooks should not focus on mere exposure to 'culture' through superficial provision of factual information, thus offering consumer-tourist competence (Byram, 1991). Conversely, their cultural-content should incite and provide opportunities for critical reflection on deeper cultural aspects so as to furnish students with cultural awareness and experiences that enhance intercultural communication (Al-Sofi, 2018). Along the same lines, Byram (1989) distinguishes cultural representation in 'cultural information', which signifies arbitrary and de-contextualized aggregate of facts in unprincipled and minimal structure, and 'cultural knowledge' that is aligned with a consciously structured presentation of ideas, concepts, facts and information including their associations.

In a similar vein, when cultural understanding is promoted, the construction of a 'third space' (Bhabha, 1997) is fostered. In particular, this emerging 'third space' constitutes a 'new culture' created by learners themselves ensuing from the amalgamation of their own 'funds of knowledge' and the target cultures encountered (Moje, McIntosh Ciechanowski, Kramer, \& Ellis, 2004). In this 'space', meanings from different cultural contexts may clash, be questioned, negotiated and problematized, while learners struggle to formulate a hybrid identity (Karras, 2018; Kramsh, 1993) and assume ownership as well as responsibility for the new meanings they communicate after challenging and re-examining long-ingrained preconceptions of the home and target society cultures (Davcheva, 2008). During this process, learners develop both an outsider's and an insider's view on their culture and the target one, which can enable them to enunciate personal meanings drawing on L1 and L2 cultures and facilitate their evolution into potent intercultural speakers and future global citizens (Thanasoulas, 2001).

\subsection{The Necessity for Textbook Evaluation in Terms of Cultural Content}

Given the skepticism surrounding the sovereignty of the TM and the overreliance on textbooks as the main input-source in ELT, textbook evaluation (TE) is deemed a necessary practice which enlightens the nature of materials (Cunningsworth, 1995; Dweik, 2007) by measuring their efficiency against specific criteria. Hence, the 
textbooks are judged in terms of contextual appropriacy, the educational methodology they reflect, the extent to which they comply with the curricular objectives and fulfill the context-driven demands, namely the learners' idiosyncrasies, backgrounds, wants, interests, preferences and expectations (Litz, 2005; Nunan, 1991). From this perspective, a systematic appraisal of the in-use instructional materials as cultural artifacts (Gray, 2000) could lead to a more culturally-oriented EFL-teaching methodology (Zhao, 2010). Likewise, Tomalin and Stempleski (2013) encourage assessing culture through the language being taught, a process which will eventually pave the way to raising CA and promoting ICC-skills (Gomez Rodriguez, 2015).

Upon these assumptions, the selection and appropriateness of the cultural-input resonate with social, political, economic, moral and religious influences underpinning the authors' rationale, policy decisions or the educational-system goals. Ergo, the design and choice of the 'cultural items' (Duenas, 1996) portrayed in textbooks can barely be identified as neutral or merely descriptive (Davcheva, 2008), given that they are carriers of certain ideological concerns and considerations which remain implicit and, therefore, constitute the often called invisible or 'hidden curriculum' (Chao, 2011).

More specifically, texts and visual illustrations may unconsciously influence beliefs, attitudes, alongside shaping behaviors and social expectations with regard to the target cultures. Furthermore, the cultural elements contained are likely to inspire or spark stereotypical views towards 'otherness' (Abrams, 2002) and nurture cultural discrimination or prejudice (Ur, 1996). Thus, TE attempts to uncover the role of 'culture' in textbooks and the importance attributed to the cultural aspects and culture-general knowledge provided (Lee, 2009). Importantly, the evaluative-criteria compilation should be aligned with the basic intercultural values and principles, namely developing and promoting IS as well as disassociating from manifestations of inherent social and cultural bias, discriminatory attitudes and stereotyping (Ur, 1996; Risager, 1991).

\section{Method}

\subsection{Research Questions}

To appraise the appropriateness and efficaciousness of the cultural-content of the 5th and 6th grade English textbooks, this research operationalizes both quantitative and qualitative instruments, thus adopting a mixed-methods research framework (Creswell, 2003; Tashakkori \& Teddlie, 2010). To this end, content analysis and a questionnaire incorporating a cultural-checklist are utilized on the quantitative side. From a qualitative perspective, EFL-teacher interviews are conducted to amplify the data-collection and ensure informed reasoning of the obtained results. The whole research was conducted during the school year 2019-2020, whereas for the research purposes the EFL-teachers were assigned an active role in the TE process by being requested to complete the cultural-checklist integrated in the questionnaire (Atai, Babaii, \& Bazargani, 2017).

Hence, the study is guided by the following research questions (RQs), which act as the main pillars in the quest to provide answers to the issues raised.

RQ1: What is the breadth and type of the cultural content included in the 5th and 6th grade state primary-school English textbooks? To what extent can it raise the learners' cultural awareness and enhance their intercultural communicative competence skills?

RQ2: Is the cultural content incorporated in the targeted textbooks effective and sufficient enough to sustain and facilitate deep culture understanding, and by extension maximize effectual language learning outcomes?

RQ3: What are the Greek EFL teachers' beliefs and attitudes towards cultural teaching practices and their perceptions of the effectiveness of the cultural representation in the specific textbooks?

\subsection{Content Analysis}

The research instrument employed to address RQ1 is the content analysis method, which can be conducted both qualitatively and quantitatively (Sandorova, 2014). The quantitative paradigm is adopted in this study for it uses a strict and systematic set of procedures to make valid inferences (Krippendorff, 2004), based on the rigorous examination of topics apropos of the inclusion of specific elements and concepts, the relationship between them along with verification of the contents of written data (Cohen, Manion, \& Morrison, 2007; Wallen \& Fraenkel, 2000).

In particular, the content analysis employs Cortazzi and Jin's (1999) proposed culture categories as a compass along with the Big ' $\mathrm{C}$ ' and small 'c' classification of cultural aspects analyzed earlier. In practice, the textbooks are numerically scrutinized and measured in terms of the cultural references made to $\mathrm{C} 1, \mathrm{C} 2$ and $\mathrm{C} 3$ so as to identify the amount of diverse cultures represented in them. This entails investigating the embedded texts, activities and projects plus the visual material integrated (Al-Sofi, 2018). In addition, the culturally-bound data 
are explored in terms of the topics selected as pertinent to Big ' $\mathrm{C}$ ' and small ' $\mathrm{c}$ ' culture elements (Lee, 2009; Xiao, 2010) and the depth attributed to them through the textbook tasks and projects.

\subsection{The Questionnaire}

The questionnaire was selected as a research tool due to its many advantages, namely its time-saving and cost-effective properties, efficacy and practicality in eliciting results on a wide spectrum along with the potential to guarantee anonymity, confidentiality and eliminate the fear of exposure for the respondents (Abolghasem, 2010). Furthermore, a questionnaire is useful, versatile, quick to implement and the data it generates can be analyzed quickly and easily (Coombe \& Davidson, 2015).

Analytically, the questionnaire comprises four sections numbering forty-four items in total. Part I focuses on demographic facts concerning the responding EFL teachers; Part II explores their intercultural stance, whereas Part III comprises two questions pertinent to mostly employed intercultural practices and the constraints potentially hindering them. Finally, Part IV contains the cultural checklist and seeks to estimate the quality and effectiveness of the cultural content in each textbook. Importantly, certain items are mixed or rephrased to serve as reliability or internal consistency checks (Bryman, 2004).

The questionnaire partly assumes the normative approach using the five-point Likert-scale in Parts II and IV for the respondents' convenience to express negative ( $1=$ strongly disagree $\& 2=$ disagree), neutral $(3=$ neither agree nor disagree) or positive ( $4=$ agree $\& 5=$ strongly agree) views on the items. Reportedly, the normative paradigm affords responses by numerous survey participants regardless of geographical limitations, while ensuring clarity and precision (Bernat \& Gvozdenko, 2005).

\subsection{The Cultural Checklist}

In a bid to obtain a more nuanced palette of information concerning the research aims (Heyvaert, Maes, \& Onghena, 2011), a checklist based on cultural indicators was regarded as essential to extract and garner the data needed. Due to their systematic, convenient and cost-efficient quality (McGrath, 2002), a plethora of checklists have been devised; however, none of them can be treated as 'sacrosanct' since each checklist is emphatically local, thus not applicable or appropriate for all teaching-contexts (Sheldon, 1988).

In this light, the designed checklist displays a combination of evaluation criteria clusters, which were compiled on the basis of several proposed checklists (Note 9) after certain modifications and adaptations. To be more explicit, the cultural checklist is composed of twenty criteria statements divided into five axes, each of which focuses on and investigates different aspects of the textbooks' cultural content with the aim to assemble the necessary data that can determine its sufficiency and appropriacy (Koroglou, 2016; Skopinskaja, 2003).

To this end, Part A assesses the textbooks' rationale and its correspondence with the pursued objectives based on two criteria; Part B comprises four criteria aiming to reveal the cultural orientation in each textbook. Part C includes nine criteria exploring the cultural content characteristics and whether/to what extent it is supported by the texts and visual illustrations, while concurrently measuring the suitability of the tasks and projects for developing CA and ICC. Part D contains two statements dealing with the intercultural issues and values promoted, whereas the three criteria in Part E potentially epitomize the overall textbook-appraisal in terms of empowering active (inter)cultural instruction.

\subsection{The Interviews}

The qualitative data were accrued by dint of in-depth interviews with respondents selected according to purposeful sampling methods, thus being reckoned 'information-rich cases' (Patton, 2002; Sandelowski, 2000). More analytically, the open-ended interview-questions were ordered abiding by the questionnaire structure and delve more profoundly into the issues raised in the study. Thereupon, the main objective was to elicit straight and largely unadorned answers by unveiling the EFL teachers' inner-thoughts, feelings and attitudes (Sandelowski, 2000).

The interview was organized around three thematic pillars consisting of 2-6 questions. Apart from the demographic-profile details firstly requested, the questions posed concerned the respondents' intercultural mindset and teaching rationale in the EFL classroom along with their views regarding the cultural content in the textbooks.

\section{Results}

\subsection{The Process of Content Analysis}

As explained earlier, content analysis was employed as a tool for collecting data regarding the textbooks' type and breadth of cultural-content. Accordingly, the methodological process involved examining the reading and 
listening texts, plus the visual illustrations of the 5th (B1) and 6th (B2) grade textbook. The results of this quest were analyzed using SPSS 21.0 statistical package so as to ensure their validity and reliability.

\subsection{Analysis of the Findings}

\subsubsection{Manifestation of Cultural Diversity}

As demonstrated in Table 1, the Pearson Chi-square test of the data gathered indicates that there is a statistically significant difference of 'culture' distribution between the textbooks. More specifically, C1 and C3 are more frequently observed in B1 than in B2, whereas $\mathrm{C} 2$ and Free/Neutral culture are more common in B2. On that account, it can be claimed that the interculturality of B1 is of markedly wider range and balance compared to B2.

Table 1. Frequency and percentage of culture distribution in the two textbooks with chi-square test

\begin{tabular}{|c|c|c|c|c|c|c|}
\hline & & Source & Target & International & Free/Neutral & Total \\
\hline \multirow[t]{4}{*}{ Textbooks } & 5th grade (B1) & 31 & 28 & 25 & 7 & 91 \\
\hline & & $34.1 \%$ & $30.8 \%$ & $27.5 \%$ & $7.7 \%$ & $100.0 \%$ \\
\hline & 6th grade $(\mathrm{B} 2)$ & 22 & 28 & 13 & 20 & 83 \\
\hline & & $26.5 \%$ & $33.7 \%$ & $15.7 \%$ & $24.1 \%$ & $100.0 \%$ \\
\hline \multirow[t]{2}{*}{ Total } & & 53 & 56 & 38 & 27 & 174 \\
\hline & & $30.3 \%$ & $32.3 \%$ & $21.6 \%$ & $15.9 \%$ & $100.0 \%$ \\
\hline Pearson Chi- & uare: 11.233 & $\mathrm{p}-\mathrm{v}$ & .011 & & & \\
\hline
\end{tabular}

\subsubsection{The Topic-Based Analysis}

In parallel, after coding and classifying the texts and activities according to the Big ' $\mathrm{C}$ ' and small ' $c$ ' culture distinction, the Chi-square test pinpoints that there is a statistically significant difference between the two variables. As shown in Table 2, small ' $c$ ' culture elements are more frequent than Big ' $\mathrm{C}$ ' ones in $\mathrm{B} 1$, whereas Big ' $\mathrm{C}$ ' culture was more often discerned than small ' $\mathrm{c}$ ' culture in $\mathrm{B} 2$, which signals a strikingly different approach towards culture treatment in each textbook.

Table 2. Frequency and percentage of Big 'C' and small 'c' cultural topics in the two textbooks with chi-square test

\begin{tabular}{lllll}
\hline & & Big C & Small c & Total \\
\hline Textbooks & 5th grade (B1) & 36 & 51 & 87 \\
& & $41.4 \%$ & $58.6 \%$ & $100.0 \%$ \\
& 6th grade (B2) & 54 & 24 & 78 \\
& & $69.2 \%$ & $30.8 \%$ & $100.0 \%$ \\
\multirow{2}{*}{ Total } & & 90 & 75 & 165 \\
& & $54.5 \%$ & $45.5 \%$ & $100,0 \%$ \\
\hline Pearson Chi-Square: 12.867 & df: 1 & p-value: $<0.001$ & & \\
\hline
\end{tabular}

\subsubsection{The Tasks Included}

Finally, a Pearson Chi-square test was conducted to assess potential differences in the distribution of Big ' $\mathrm{C}$ ' and small ' $\mathrm{c}$ ' thematic areas in tandem with $\mathrm{C} 1, \mathrm{C} 2, \mathrm{C} 3$ orientation in the tasks and the suggested project-work in each textbook, not failing to consider those having non-culture or neutral focus. As illustrated in Table 3, there is a statistically significant difference between the two variables. 
Table 3. Frequency and percentage of the distribution of Big ' $\mathrm{C}$ ' compared to small ' $\mathrm{c}$ ' cultural elements in the tasks of each unit in the two textbooks and their categorization into $\mathrm{C} 1, \mathrm{C} 2$ and $\mathrm{C} 3$ and non-culture related elements with a chi-square test

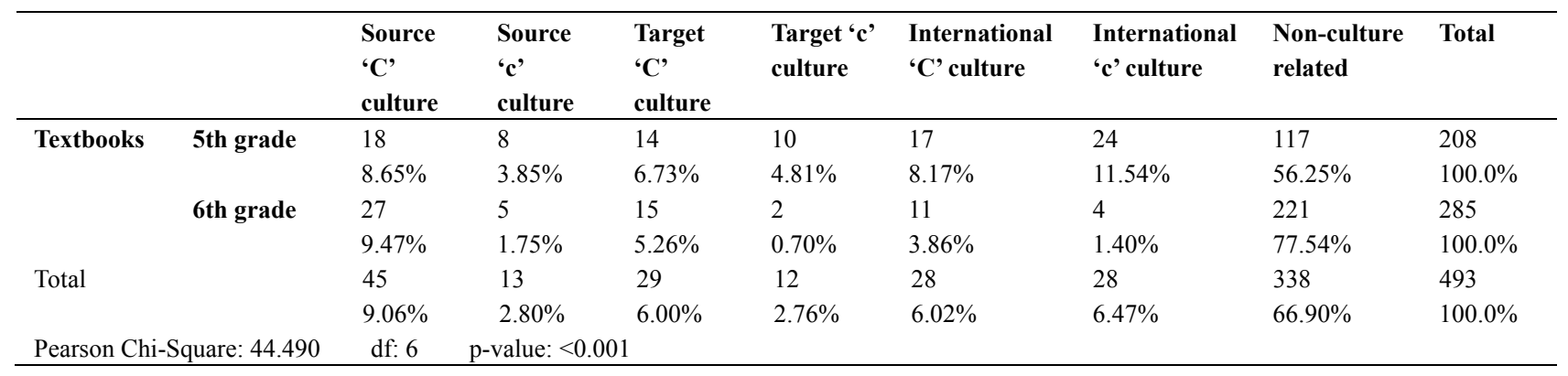

Interestingly, as evidenced in the findings the vast majority of tasks in both textbooks are identified culturally neutral. In effect, they primarily focus on the correct implementation of grammar rules and vocabulary, thus enhancing linguistic competence and accuracy at the expense of raising CA and inculcating ICC-skills. More explicitly, greater emphasis is placed on tasks involving Big ' $\mathrm{C}$ ' culture in the textbooks, whereas small ' $\mathrm{c}$ ' culture-oriented tasks do not abound in either textbook with a noteworthy exception in the analogy of $\mathrm{C} 3$ in small ' $\mathrm{c}$ ' related tasks in B1.

Comparatively, the tasks and projects included in B1 are distinctly more reflective of its intercultural dimension and the cultural aspects covered are indicative of the authors' attempt to meet the curricular requirements regarding the multicultural approach sought after. By contrast, B2 displays less interculturality due to exhibiting cultural incidences generally confined to Big ' $\mathrm{C}$ ' cultural items in tasks, thus failing to provide students adequate and well-rounded exposure to cultural diversity.

\subsubsection{Critical Assessment of the Content Analysis}

Overall, having the content analysis findings as a precursor to the evaluation of the type and breadth of the textbooks' cultural input (Littlejohn, 2011), imbalanced attention is readily detected concerning the distribution of cultural occurrences in visual and written modalities (Aliakbari \& Jamalvandi, 2013) pertinent to the different culture categories. The same inequality is discernible considering the prevalence of the Big ' $\mathrm{C}$ ' cultural aspects at the expense of small ' $c$ ' ones, which does not foster the development of the learners' ICC (Nguyen, 2011; Yuen, 2011). Practically, B1 is undoubtedly more culturally-loaded in terms of topic-selection and intercultural orientation. Conversely, B2 lacks equilibrium with respect to the inclusion of the three culture categories $(\mathrm{C} 1, \mathrm{C} 2$, C3) and range of cultural topics, whereas a substantial part of the book is identified as culture-free.

\subsection{The E-Questionnaire Results}

Accordingly, the analysis of the e-questionnaire data is quite elucidating as regards the EFL teachers' intercultural approach and instructional practices. In particular, Part II reveals that most of the teachers voice positive predispositions towards 'culture teaching', as they agree $(47.66 \%)$ or strongly agree $(34.58 \%)$ that it is as important as teaching linguistic skills and that it should be fully incorporated in ELT in multiple ways ( $4=48.60 \% \& 5=45.79 \%$ ). Likewise, it is strongly claimed that 'culture teaching' is motivating for EFL-learners given the percentages allotted to rates $4(=48.60 \%)$ and $5(=36.45 \%)$. Observably, variety of opinion is recorded when it comes to integrating 'culture teaching' into the teaching practices as $40.19 \%$ ( $=2)$ of the respondents do not find such venture difficult to achieve, whereas $28.04 \%(=3)$ feel neutral about it. Regarding the amount of time devoted to 'culture teaching' compared to 'language teaching', mixed views are expressed as $28.97 \%$ of the teachers disagree, $34.58 \%$ are neutral and $24.30 \%$ agree with spending equal time on each teaching component. As appears, the EFL-classroom is acknowledged as a safe environment to implement intercultural teaching practices taking into account that positive responses $(4=42.99 \% \& 5=37.38 \%)$ were mainly given.

Moreover, raising the learners' awareness of cultural diversity is clearly a top priority for the Greek EFL teachers (4=35.51\% \& $5=29.91 \%)$ and, seemingly, teaching intercultural values such as IS, tolerance of cultural differences and shaping positive attitudes towards 'otherness' is attached paramount importance $(4=41.12 \% \&$ $5=53.27 \%$ ). Additionally, a large proportion believes that CA fosters EFL learning and maximizes the learning outcomes $(4=46.73 \% \& 5=29.91 \%)$, whereas acquiring ICC-skills is viewed as an indisputably vital asset for EFL learners $(4=44.85 \% \& 5=41.12 \%)$. Similarly, teachers almost massively agree $(43.93 \%=4)$ or strongly agree $(50.47 \%=5)$ that developing CA and ICC enhances successful intercultural communication and helps avoid 
misunderstandings and cultural conflicts that may lead to miscommunication.

Furthermore, the respondents express disagreement towards teaching cultural aspects exclusively connected with British and American culture ( $1=30.84 \%$ \& $2=40.19 \%)$, which denotes willingness to espouse an intercultural approach. This attitude is verified by advocating $(4=38.32 \% \& 5=54.21 \%)$ the students' need to explore and understand their own culture along with various foreign cultures they encounter as global community members. Notably, the participants adjudge the currently used teaching materials as inadequate tools to facilitate 'culture teaching' in primary schools by expressing basically negative $(1=32.71 \% \& 2=40.19 \%)$ and neutral $(3=24.30 \%)$ views. Lastly, it is emphatically ascertained and particularly comforting that EFL-teachers barely rely on the prescribed English textbooks regarding 'culture teaching' $(1=45.79 \% \& 2=35.51 \%)$.

Last but not least, Part III exhibits the most operationalized intercultural practices implemented in the EFL classroom, namely using authentic material, encouraging learners to compare their culture with other target cultures, employing computer-mediated intercultural learning techniques and initiating whole-class discussions regarding issues of cultural diversity and IS. As for the most prevailing barriers potentially impeding or negatively impacting culture teaching, time constraints are in the highest rank, followed by lack of appropriate and reliable audiovisual equipment and adequate teaching resources.

\subsection{The Cultural Checklist}

As mentioned, the checklist serves as an ancillary lens into the cultural portrayal of the assigned textbooks and assesses its match with a particular purpose (Zhang, 2017) which is its contribution to the students' CA and ICC-skills, assumed to prepare them for intercultural citizenship in our globalized world (Kiss \& Weninger, 2013). In attempting an in-depth appraisal that ensures systematicity, clarity and practicality, a five-point rating scale ( $1=$ not at all, $2=$ slightly, $3=$ moderately, $4=$ much, $5=$ to a great extent) is utilized to gauge the content quality from a cultural viewpoint, impart the underlying philosophy and detect potential defects and deficiencies (Karavas, 2004).

Starting off, in Part A the majority of participants feel that B1 does not effectively correspond to the needs and goals of learners as EIL speakers by predominantly selecting $2(35.51 \%)$ or $3(30.84 \%)$. B2 is also rated as moderately $(42.06 \%)$ catering for the same variables, thereby mirroring identical opinions. Accordingly, the aims and objectives of B1 seem slightly (35.51\%) or moderately $(33.64 \%)$ congruent with the multicultural perspective advocated by the National EFL curriculum. B2 seems to be moving in the same direction, yet a little closer to the curricular outlook $(2=32.71 \%$ \& $3=34.78 \%)$.

As regards the textbooks' cultural orientation, the responses to the first item in Part B indicate that the topics chosen are not really suitable for the learners' diverse social and cultural background, since the percentages allotted to rates 2 and 3 are overwhelming for both textbooks $(36.45 \% \& 26.17 \%$-B1 vs. $32.71 \& 35.51 \%$-B2). Furthermore, the textbooks are not believed to be oriented towards other cultures except British or American with the relevant inclination fluctuating among rates 1,2 and $3(25.23 \%, 41.12 \%, 22.43 \%$-B1 vs. $24.30 \%$, $35.51 \%, 30.84-\mathrm{B} 2)$. The presence of characters from different cultural and ethnic backgrounds is considered mostly slight $(31.08 \%$-B1 vs. $29.91 \%$-B2) or moderate $(33.64 \%-B 1$ vs. $29.91 \%$-B2) in both textbooks, thus displaying similarity in their analogy judging from the percentages. Noticeably, cultural input is slightly or moderately provided in all units $(2=36.45 \%$ \& $3=33.64 \%$-B1 vs. $2=39.25 \% \& 3=30.84 \%-B 2)$.

Part $\mathrm{C}$ uncovers the cultural-content characteristics by thoroughly inspecting its general aims and the degree to which the tasks and activities raise the 5th and 6th graders' CA and promote their ICC. In this sense, the cultural input in B1 is regarded as not at all (31.78\%) or slightly (41.12\%) challenging enough to arouse the learners' curiosity about other cultures and enrich their CA, while in B2 it is reviewed as slightly $(38.32 \%)$ or moderately (28.97\%) motivating. Similarly, the existing cultural aspects in B1 are not at all (28.97\%) or slightly (32.71\%) comprehensible and appropriate for the learners' age and linguistic level as contrasted with B2, which appears to be slightly (42.06) or moderately $(27.10 \%)$ satisfying from this angle.

Furthermore, the cultural-content in both textbooks is presented as rather isolated facts or improperly contextualized $(2=37.38 \%, 3=39.25 \%$-B1 vs. $2=35.51 \%, 3=38.32 \%$-B2 $)$, which adds to its previously implied inadequacy. This finding is corroborated by the glaring weaknesses identified in the textbooks, namely the lack of engaging texts, illustrations/images and listening material $(1=40.19 \%, 2=41.12 \%$-B1 vs. $1=30.84 \%$, $2=42.99 \%$-B2) that could facilitate in-depth understanding of diverse cultures. Understandably, the textbook activities are hardly conducive to the students' critical cultural reflection that ensues from comparing and contrasting their own culture to other cultures as depicted in the ratings $(2=47.66 \%, 3=26.17 \%$-B1 vs. $2=43.93 \%$, $3=30.84 \%-B 2$ ). 
In addition, the results revealed that the tasks are slightly (43.93\%) or not at all (30.84\%) perceived to be facilitative to explicating or consolidating the cultural information supplied in B1, which signifies that learners are not actively involved in observation, interpretation and discussion of the cultural aspects portrayed. Comparably, more than half participants (52.34\%) consider B2 tasks slightly supportive of the cultural input incorporated. As regards the cross-cultural projects and creative activities in B1, the tendency towards rates 2 $(41.12 \%)$ and $3(26.17 \%)$ is distinct, thus indicating that they slightly or moderately foster and promote the experiential dimension of culture-learning. Almost the same applies for B2 about which opinions are divided between rates $2(35.51 \%)$ and $3(36.45 \%)$.

Finally, the cultural-content embedded in both B1 $(1=34.58 \%, 2=36.45)$ and B2 $(1=28.04 \%, 2=40.19 \%)$ is defined as not at all or slightly authentic and hardly up-to-date given the analogies (B1:1=50.47\%, $2=35.51 \%$ vs. $\mathrm{B} 2: 1=49.53 \%, 2=35.51 \%$ ) corresponding to the last criterion in this part. Such findings endorse and ratify the previously ascertained deficiencies in the textbooks and point out their shallow and superficial culture treatment.

Part $\mathrm{D}$, which scrutinizes the intercultural values and issues dealt with, indicates that in terms of stereotypical images and references to race, religion and gender, the cultural-content of B1 is assessed as rather moderately (43.93\%) loaded. B2 displays interchangeable propensity, translated in $48.60 \%$ for moderate existence of such depiction. Likewise, regarding the extent to which the textbooks promote intercultural values, responses oscillate between rates 2 and $3(2=35.51 \% \& 3=32.71 \%-\mathrm{B} 1$ vs. $2=32.71 \% \& 3=34.58 \%-\mathrm{B} 2)$.

Part E serves as an epitome of all the hitherto analyzed criteria focusing on the textbooks' overall appraisal. Firstly, their cultural-content is evaluated with regard to its contribution to the construction of a 'third space', which affords learners the opportunity to function as 'international speakers'. Importantly, the broad majority of participants regards B1 as slightly $(42.99 \%)$ or not at all $(28.57 \%)$ conducive to the 'third space' formation, and B2 as slightly $(41.12 \%)$ or moderately $(28.04 \%)$ contributory to this goal. Secondly, judging from the relevant ratings $(1=27.10 \% \& 2=43.93 \%)$, B1 fails to adopt a holistic approach to understanding different cultures and communication styles of EIL; B2 is graded closer to this direction, thus swaying between slight $(2=40.19 \%)$ and moderate $(3=32.71 \%)$ indices. The last criterion inquires whether the textbooks can effectively suffice for potent (inter)cultural instruction without additional supplementary material. As anticipated, neither textbook is deemed sufficient given the immense percentage allocated to rate 1 (58.88\%-B1 vs. $53.27 \%$-B2).

In essence, it becomes obvious that culture representation in both textbooks is confined to tangible aspects of cultural knowledge. This equals purely transmitting cultural information based on a haphazard selection of cultural items that barely offer a balanced view of world cultures or create opportunities for authentic cultural experiences, thus failing to function as a window to learning about and exploring different cultures.

\subsection{The Teacher Interviews}

As noted earlier, the semi-structured interviews probe deeper into the issues of interest discussed, eliciting more accurate information and generating new verbal insights (Robson, 2007) into the EFL teachers' attitudes and practices towards 'culture' along with their predispositions regarding the textbooks' cultural content. Given that the interview questions are in keeping with the questionnaire layout, the interviewees' responses were evaluated in conjunction with the questionnaire findings and, broadly speaking, convergent views surfaced.

More explicitly, it became crystal clear that despite the fact that the EFL teachers place high importance on 'culture teaching' and transmitting intercultural values, the cultural content in the assigned textbooks was unanimously assessed as simply inadequate to enable learners to critically reflect on cultural issues at a deeper niveau (Karras, 2021). Therefore, but for the teachers' concerted efforts to create a stimulating context that embraces cultural diversity and develop the students' intercultural perspective, the latter would be superficially exposed to culture and deprived of any interculturally-rich experiences. Therefore, the interview analysis corroborates and supplements the questionnaire results, thus adding to the validity, trustworthiness and reliability of the research outcomes (Richards, 2003).

\subsection{Statistics and Data Analysis}

To further validate the e-questionnaire findings, reliability tests were conducted using Cronbach's Alpha coefficient (Cronbach, 1951) so as to measure the internal consistency of the multiple-question Likert scale survey. As regards the second part of the questionnaire exploring the EFL practitioners' perceptions of 'culture-teaching', the test showed acceptable reliability considering the value 0.718 (Note 10) calculated (Table 4). Additional exploratory factor analysis was performed to check dimensionality by assessing the reliability of responses regarding the place of 'culture' in the EFL-classroom (factor 1: items 5-7) and the impact of intercultural teaching (factor 2: items 8-11) on language learning outcomes. The relevant values (factor $1=0.715$ 
$\&$ factor $2=0.822$ ) also indicated acceptable and good reliability respectively (Table 5 ).

Table 4. Teachers' beliefs and attitudes regarding (inter)cultural teaching in the state primary-school EFL-classroom

\begin{tabular}{|c|c|c|c|c|c|c|}
\hline & $\mathbf{N}$ & Mean & $\begin{array}{l}\text { Std. } \\
\text { Deviation }\end{array}$ & Minimum & Maximum & $\begin{array}{l}\text { Cronbach's } \\
\text { alpha }\end{array}$ \\
\hline 'Culture teaching' is as important as teaching linguistic skills & 107 & 4.13 & 0.79 & 2 & 5 & 0.718 \\
\hline $\begin{array}{l}\text { 'Culture teaching' should be fully incorporated in ELT in a number } \\
\text { of ways }\end{array}$ & 107 & 4.39 & 0.63 & 2 & 5 & \\
\hline 'Culture teaching' is motivating for the EFL students. & 107 & 4.19 & 0.75 & 2 & 5 & \\
\hline $\begin{array}{l}\text { It is difficult to integrate 'culture teaching' into my teaching } \\
\text { practices }\end{array}$ & 107 & 2.44 & 1.00 & 1 & 5 & \\
\hline $\begin{array}{l}\text { Equal time should be devoted to 'language teaching' and 'culture } \\
\text { teaching' respectively despite time and other constraints }\end{array}$ & 107 & 3.16 & 1.00 & 1 & 5 & \\
\hline $\begin{array}{l}\text { The EFL classroom is a safe environment to implement intercultural } \\
\text { teaching practices }\end{array}$ & 107 & 4.11 & 0.88 & 1 & 5 & \\
\hline $\begin{array}{l}\text { Raising the students' awareness of cultural diversity is a top priority } \\
\text { in the EFL classroom }\end{array}$ & 107 & 3.84 & 0.99 & 1 & 5 & \\
\hline $\begin{array}{l}\text { It is important to teach students intercultural values such as } \\
\text { intercultural sensitivity, respect/tolerance of cultural differences and } \\
\text { shaping positive attitudes towards 'otherness' }\end{array}$ & 107 & 4.48 & 0.60 & 3 & 5 & \\
\hline $\begin{array}{l}\text { Cultural awareness fosters EFL learning and maximizes the learning } \\
\text { outcomes }\end{array}$ & 107 & 4.05 & 0.77 & 2 & 5 & \\
\hline $\begin{array}{l}\text { Acquiring intercultural communicative competence skills is an } \\
\text { important asset for EFL learners }\end{array}$ & 107 & 4.24 & 0.78 & 1 & 5 & \\
\hline $\begin{array}{l}\text { Developing cultural awareness and intercultural communicative } \\
\text { competence enhances successful intercultural communication (e.g., } \\
\text { helps avoid misunderstandings, cultural conflicts, } \\
\text { miscommunication etc.) }\end{array}$ & 107 & 4.44 & 0.63 & 2 & 5 & \\
\hline $\begin{array}{l}\text { The cultural aspects taught in the EFL classroom should be } \\
\text { exclusively connected with British or American culture (Native } \\
\text { Speaker culture) }\end{array}$ & 107 & 2.16 & 1.08 & 1 & 5 & \\
\hline $\begin{array}{l}\text { Students need to explore and understand their own culture as well as } \\
\text { various foreign cultures since they are members of a global } \\
\text { community }\end{array}$ & 107 & 4.45 & 0.69 & 2 & 5 & \\
\hline $\begin{array}{l}\text { The teaching materials currently employed in state primary school } \\
\text { (textbook, workbook, etc.) are adequate tools to facilitate culture } \\
\text { teaching }\end{array}$ & 107 & 1.97 & 0.83 & 1 & 4 & \\
\hline I strongly rely on the prescribed textbooks for culture teaching & 107 & 1.81 & 0.93 & 1 & 4 & \\
\hline
\end{tabular}

Table 5. Teachers' beliefs and attitudes regarding (inter)cultural teaching in state primary-school as far as factors $1 \& 2$ are concerned

\begin{tabular}{lllllll}
\hline & N & Mean & Std. Deviation & Minimum & Maximum & Cronbach's alpha \\
\hline $\begin{array}{l}\text { Teachers' beliefs and attitudes regarding the place of } \\
\text { 'culture-teaching' in the state primary-school }\end{array}$ & 107 & 3.70 & 0.77 & 2.00 & 5.00 & 0.715 \\
$\begin{array}{l}\text { EFL-classroom_factor1(Part II: items 5-7) } \\
\begin{array}{l}\text { Teachers' beliefs and attitudes regarding the impact of } \\
\text { intercultural teaching on language learning outcomes } \\
\text { factor2 (Part II: items 8-11) }\end{array}\end{array}$ & 107 & 4.30 & 0.57 & 2.75 & 5.00 & 0.822 \\
\hline
\end{tabular}

Additionally, the cultural checklist results pertinent to the textbooks' overall cultural-content evaluation and appropriacy indicated 'excellent' (Note 11) reliability given the high values obtained (0.937-B1 \& 0.934-B2) after conducting the Cronbach's Alpha coefficient (Tables 6 and 7). The same acceptably correlated values are observed in the additional tests performed for each part separately (Tables 8 and 9), except for poor interrelatedness detected in the fourth part regarding the intercultural values conveyed by the textbooks (0.411-B1 vs. 0.369-B2). This can be attributed to chance or arbitrary choices made by the participants or absence of enough questions to rate the specific variable (Tavakol \& Dennick, 2011). 
Table 6. Teachers' responses in relation to their perception of the cultural representation in the 5th grade textbook

\begin{tabular}{|c|c|c|c|c|c|c|}
\hline & $\mathbf{N}$ & Mean & Std. Deviation & Minimum & Maximum & Cronbach's alpha \\
\hline 5th grade textbook & & & & & & 0.937 \\
\hline $\begin{array}{l}\text { The textbook caters for the needs and goals of students as } \\
\text { international English speakers. }\end{array}$ & 107 & 2.2 & 0.9 & 1 & 5 & \\
\hline $\begin{array}{l}\text { The aims/objectives of the textbook are in accordance with the } \\
\text { multicultural perspective advocated by the National EFL } \\
\text { curriculum. }\end{array}$ & 107 & 2.5 & 1.0 & 1 & 5 & \\
\hline $\begin{array}{l}\text { The topics chosen are suitable for the students' diverse social } \\
\text { and cultural background. }\end{array}$ & 107 & 2.3 & 1.0 & 1 & 5 & \\
\hline $\begin{array}{l}\text { The textbook is culturally oriented towards other cultures } \\
\text { except British/American. }\end{array}$ & 107 & 2.2 & 0.9 & 1 & 4 & \\
\hline $\begin{array}{l}\text { The textbook features characters from different cultural and } \\
\text { ethnic backgrounds. }\end{array}$ & 107 & 2.7 & 1.1 & 1 & 5 & \\
\hline The textbook provides cultural input in all units. & 107 & 2.4 & 0.9 & 1 & 4 & \\
\hline $\begin{array}{l}\text { The cultural content in the textbook is motivating/challenging } \\
\text { enough to arouse the learners' curiosity about other cultures } \\
\text { and enhance their cultural awareness. }\end{array}$ & 107 & 2.0 & 0.9 & 1 & 4 & \\
\hline $\begin{array}{l}\text { The cultural aspects presented are comprehensible and } \\
\text { appropriate for the learners' age and linguistic level. }\end{array}$ & 107 & 2.3 & 1.1 & 1 & 5 & \\
\hline $\begin{array}{l}\text { The cultural content is integrated (if it is presented in context } \\
\text { give a score of } 3,4 \text { or } 5 \text {; if it is presented as isolated facts give } \\
1 \text { or 2). }\end{array}$ & 107 & 2.4 & 0.9 & 1 & 5 & \\
\hline $\begin{array}{l}\text { The textbook includes engaging texts, images/illustrations and } \\
\text { listening material that promote in-depth understanding of } \\
\text { different cultures. }\end{array}$ & 107 & 1.8 & 0.8 & 1 & 4 & \\
\hline $\begin{array}{l}\text { The textbook activities prompt students to reflect on, compare } \\
\text { and contrast their own culture to other cultures. }\end{array}$ & 107 & 2.2 & 0.9 & 1 & 5 & \\
\hline $\begin{array}{l}\text { The textbook tasks/activities consolidate/further explain the } \\
\text { cultural information provided so as to actively involve the } \\
\text { learners into observation/identification, interpretation and } \\
\text { discussion of the cultural aspects presented. }\end{array}$ & 107 & 2.0 & 0.9 & 1 & 4 & \\
\hline $\begin{array}{l}\text { The textbook includes cross-cultural projects and creative } \\
\text { activities that facilitate and promote the experiential } \\
\text { dimension of culture learning. }\end{array}$ & 107 & 2.3 & 1.0 & 1 & 5 & \\
\hline $\begin{array}{l}\text { The cultural content (reading/listening input, illustrations, } \\
\text { etc.) included in the textbook is authentic. }\end{array}$ & 107 & 2.0 & 1.0 & 1 & 5 & \\
\hline The cultural input embedded in the textbook is up-to-date. & 107 & 1.7 & 0.8 & 1 & 4 & \\
\hline $\begin{array}{l}\text { The cultural content of the textbook is bereft of stereotypical } \\
\text { images/information regarding race, religion, gender, etc. }\end{array}$ & 107 & 3.1 & 1.0 & 1 & 5 & \\
\hline $\begin{array}{l}\text { The textbook promotes intercultural values such as } \\
\text { understanding, tolerance, empathy, respectful attitudes and } \\
\text { openness towards 'otherness', intercultural sensitivity and } \\
\text { acceptance. }\end{array}$ & 107 & 2.5 & 1.0 & 1 & 5 & \\
\hline $\begin{array}{l}\text { The cultural content provided fosters the construction of a } \\
\text { 'third space' (where learners can begin to function as } \\
\text { international speakers). }\end{array}$ & 107 & 2.0 & 0.8 & 1 & 4 & \\
\hline $\begin{array}{l}\text { The textbook adopts a holistic approach to understanding } \\
\text { diverse cultures and communication styles of English as an } \\
\text { international language. }\end{array}$ & 107 & 2.1 & 0.8 & 1 & 5 & \\
\hline $\begin{array}{l}\text { The textbook can effectively suffice for active (inter)cultural } \\
\text { instruction and no additional material is required to } \\
\text { supplement it. }\end{array}$ & 107 & 1.5 & 0.7 & 1 & 4 & \\
\hline
\end{tabular}


Table 7. Teachers' responses in relation to their perception of the cultural representation in the 6 th grade textbook

\begin{tabular}{|c|c|c|c|c|c|c|}
\hline & $\mathbf{N}$ & Mean & Std. Deviation & Minimum & Maximum & Cronbach's alpha \\
\hline 6th grade textbook & & & & & & 0.934 \\
\hline $\begin{array}{l}\text { The textbook caters for the needs and goals of students as } \\
\text { international English speakers. }\end{array}$ & 107 & 2.44 & 0.94 & 1 & 5 & \\
\hline $\begin{array}{l}\text { The aims/objectives of the textbook are in accordance } \\
\text { with the multicultural perspective advocated by the }\end{array}$ & 107 & 2.62 & 0.97 & 1 & 5 & \\
\hline National EFL curriculum. & & & & & & \\
\hline $\begin{array}{l}\text { The topics chosen are suitable for the students' diverse } \\
\text { social and cultural background. }\end{array}$ & 107 & 2.52 & 0.96 & 1 & 5 & \\
\hline $\begin{array}{l}\text { The textbook is culturally oriented towards other cultures } \\
\text { except British/American. }\end{array}$ & 107 & 2.26 & 0.95 & 1 & 5 & \\
\hline $\begin{array}{l}\text { The textbook features characters from different cultural } \\
\text { and ethnic backgrounds. }\end{array}$ & 107 & 2.62 & 1.06 & 1 & 5 & \\
\hline The textbook provides cultural input in all units. & 107 & 2.35 & 0.91 & 1 & 4 & \\
\hline $\begin{array}{l}\text { The cultural content in the textbook is } \\
\text { motivating/challenging enough to arouse the learners' } \\
\text { curiosity about other cultures and enhance their cultural } \\
\text { awareness. }\end{array}$ & 107 & 2.19 & 0.90 & 1 & 4 & \\
\hline $\begin{array}{l}\text { The cultural aspects presented are comprehensible and } \\
\text { appropriate for the learners' age and linguistic level. }\end{array}$ & 107 & 2.38 & 0.99 & 1 & 5 & \\
\hline $\begin{array}{l}\text { The cultural content is integrated (if it is presented in } \\
\text { context give a score of } 3,4 \text { or } 5 \text {; if it is presented as } \\
\text { isolated facts give } 1 \text { or } 2 \text { ). }\end{array}$ & 107 & 2.50 & 0.90 & 1 & 5 & \\
\hline $\begin{array}{l}\text { The textbook includes engaging texts, } \\
\text { images/illustrations and listening material that promote } \\
\text { in-depth understanding of different cultures. }\end{array}$ & 107 & 1.97 & 0.79 & 1 & 4 & \\
\hline $\begin{array}{l}\text { The textbook activities prompt students to reflect on, } \\
\text { compare and contrast their own culture to other cultures. }\end{array}$ & 107 & 2.27 & 0.89 & 1 & 5 & \\
\hline $\begin{array}{l}\text { The textbook tasks/activities consolidate/further explain } \\
\text { the cultural information provided so as to actively } \\
\text { involve the learners into observation/identification, } \\
\text { interpretation and discussion of the cultural aspects } \\
\text { presented. }\end{array}$ & 107 & 2.05 & 0.73 & 1 & 4 & \\
\hline $\begin{array}{l}\text { The textbook includes cross-cultural projects and } \\
\text { creative activities that facilitate and promote the } \\
\text { experiential dimension of culture learning. }\end{array}$ & 107 & 2.36 & 0.89 & 1 & 4 & \\
\hline $\begin{array}{l}\text { The cultural content (reading/listening input, } \\
\text { illustrations, etc) included in the textbook is authentic. }\end{array}$ & 107 & 2.13 & 0.94 & 1 & 5 & \\
\hline $\begin{array}{l}\text { The cultural input embedded in the textbook is } \\
\text { up-to-date. }\end{array}$ & 107 & 1.69 & 0.82 & 1 & 4 & \\
\hline $\begin{array}{l}\text { The cultural content of the textbook is bereft of } \\
\text { stereotypical images/information regarding race, } \\
\text { religion, gender, etc. }\end{array}$ & 107 & 3.06 & 0.97 & 1 & 5 & \\
\hline $\begin{array}{l}\text { The textbook promotes intercultural values such as } \\
\text { understanding, tolerance, empathy, respectful attitudes } \\
\text { and openness towards 'otherness', intercultural } \\
\text { sensitivity and acceptance. }\end{array}$ & 107 & 2.49 & 0.99 & 1 & 5 & \\
\hline $\begin{array}{l}\text { The cultural content provided fosters the construction of } \\
\text { a 'third space' (where learners can begin to function as } \\
\text { international speakers). }\end{array}$ & 107 & 2.08 & 0.84 & 1 & 4 & \\
\hline $\begin{array}{l}\text { The textbook adopts a holistic approach to understanding } \\
\text { diverse cultures and communication styles of English as } \\
\text { an international language. }\end{array}$ & 107 & 2.09 & 0.82 & 1 & 5 & \\
\hline $\begin{array}{l}\text { The textbook can effectively suffice for active } \\
\text { (inter)cultural instruction and no additional material is } \\
\text { required to supplement it. }\end{array}$ & 107 & 1.55 & 0.68 & 1 & 3 & \\
\hline
\end{tabular}


Table 8. Teachers' responses in relation to the cultural criteria clusters in the 5 th grade textbook

\begin{tabular}{lllllll}
\hline & N & Mean & Std. Deviation & Minimum & Maximum & Cronbach's alpha \\
\hline Rationale and Objectives & 107 & 2.38 & 0.88 & 1.00 & 4.50 & 0.812 \\
Cultural orientation/representation & 107 & 2.41 & 0.79 & 1.00 & 4.00 & 0.800 \\
Cultural content characteristics & 107 & 2.09 & 0.67 & 1.00 & 4.11 & 0.892 \\
(aim/objectives, activities/tasks, suitability) & & & & & & \\
Intercultural issues/values & 107 & 2.78 & 0.79 & 1.00 & 4.50 & 0.411 \\
Overall appraisal of the textbooks & 107 & 1.86 & 0.67 & 1.00 & 3.67 & 0.815 \\
\hline
\end{tabular}

Table 9. Teachers' responses in relation to the cultural criteria clusters in the 6th grade textbook

\begin{tabular}{lllllll}
\hline & N & Mean & Std. Deviation & Minimum & Maximum & Cronbach's alpha \\
\hline Rationale and Objectives & 107 & 2.53 & 0.87 & 1.00 & 4.00 & 0.781 \\
Cultural orientation/representation & 107 & 2.44 & 0.77 & 1.00 & 4.00 & 0.794 \\
Cultural content characteristics & 107 & 2.17 & 0.62 & 1.00 & 3.56 & 0.879 \\
(aim/objectives, activities/tasks, suitability) & & & & & & \\
Intercultural issues/values & 107 & 2.77 & 0.77 & 1.00 & 4.50 & 0.369 \\
Overall appraisal of the textbooks & 107 & 1.91 & 0.68 & 1.00 & 3.33 & 0.844 \\
\hline
\end{tabular}

More specifically, to assess the correlation between the respondents' age and their attitudes towards 'culture-teaching', Kruskal-Wallis H test was selected to measure any statistically significant differences among the diverse age groups in relation to five factors comprising different items from the second part of the questionnaire. As shown in Table 10, the age variable does not influence the teachers' intercultural approaches given that the estimated $p$-value is $\geq 0.05$. Similarly, another parameter investigated is whether the respondents' attendance of intercultural training seminars affects their predispositions to 'culture teaching'. In this case the Mann-Whitney $U$ test was conducted to compare the medians between the interculturally trained and untrained EFL teachers (Klotz, 2006). As Table 11 encapsulates ( $p$-value $\geq 0.05$ ) the EFL-educators' manifest positive approach to 'culture teaching' is not dependent on intercultural seminar attendance.

Table 10. Results of Kruskal-Wallis $\mathrm{H}$ test measuring the correlation between the participants' intercultural stance and their age

\begin{tabular}{lllllll}
\hline & Age & N & Median & Mean Rank & Kruskal Wallis H & p-value \\
\hline Factor 1 (items 1-4) & $31-40$ & 41 & 3.75 & 52.65 & 0.148 & 0.929 \\
& $41-50$ & 48 & 3.75 & 55.15 & & \\
& $51+$ & 18 & 3.88 & 54.03 & & 0.263 \\
Factor 2 (items 5-7) & $31-40$ & 41 & 3.67 & 51.68 & 2.670 & \\
& $41-50$ & 48 & 3.67 & 51.93 & & 0.760 \\
Factor 3 (items 8-11) & $51+$ & 18 & 4.00 & 64.81 & & \\
& $31-40$ & 41 & 4.25 & 51.24 & 0.550 & 0.330 \\
Factor 4 (items 12-13) & $41-50$ & 48 & 4.38 & 55.96 & & \\
& $51+$ & 18 & 4.38 & 55.06 & & \\
& $31-40$ & 41 & 3.00 & 49.15 & 2.216 & \\
Factor 5 (items 14-15) & $41-50$ & 48 & 3.00 & 55.71 & & \\
& $51+$ & 18 & 3.50 & 60.5 & & \\
& $31-40$ & 41 & 2.00 & 53.12 & 0.070 & \\
\hline
\end{tabular}


Table 11. Results of Mann-Whitney U test correlating the teachers' beliefs and attitudes regarding (inter)cultural teaching and their potential intercultural training

\begin{tabular}{|c|c|c|c|c|c|c|}
\hline & $\begin{array}{l}\text { Have you attended any } \\
\text { seminars/training courses on } \\
\text { intercultural education during your } \\
\text { professional career? }\end{array}$ & $\mathbf{N}$ & Median & $\begin{array}{l}\text { Mean } \\
\text { Rank }\end{array}$ & $\begin{array}{l}\text { Mann-Whitney } \\
\text { U }\end{array}$ & p-value \\
\hline \multirow[t]{2}{*}{ Factor 1 (items 1-4) } & No & 77 & 3.75 & 51.71 & 978.50 & 0.214 \\
\hline & Yes & 30 & 4.00 & 59.88 & & \\
\hline \multirow[t]{2}{*}{ Factor 1 (items 5-7) } & No & 77 & 3.67 & 50.91 & 917.00 & 0.096 \\
\hline & Yes & 30 & 4.00 & 61.93 & & \\
\hline \multirow[t]{2}{*}{ Factor 1 (items 8-11) } & No & 77 & 4.25 & 50.82 & 910.00 & 0.085 \\
\hline & Yes & 30 & 4.62 & 62.17 & & \\
\hline \multirow[t]{2}{*}{ Factor 1 (items 12-13) } & No & 77 & 3.00 & 53.38 & 1107.50 & 0.725 \\
\hline & Yes & 30 & 3.00 & 55.58 & & \\
\hline \multirow[t]{2}{*}{ Factor 1 (items 14-15) } & No & 77 & 2.00 & 52.33 & 1026.50 & 0.358 \\
\hline & Yes & 30 & 2.00 & 58.28 & & \\
\hline
\end{tabular}

Lastly, the Spearman correlation coefficient $\left(\mathrm{r}_{\mathrm{s}}\right)$ was employed to measure the strength and direction of association between paired data. Particularly, the overall perception of the cultural representation in the textbooks depicts the respondents' convergence of opinion according to the retrieved values in all the examined variables (Table 12). Their interpretation is that the closer they are to \pm 1 , the stronger the monotonic relationship is calculated, thus confirming their strongly negative proclivity towards both textbooks' cultural-content.

Table 12. Spearman correlation coefficient measuring the teachers' perceptions of the 'cultural representation' in the 5th and 6th grade state-school English textbooks

\begin{tabular}{|c|c|c|c|c|c|c|}
\hline & & \multicolumn{5}{|l|}{ 5th grade } \\
\hline & & $\begin{array}{l}\text { Rationale } \\
\text { and } \\
\text { Objectives }\end{array}$ & $\begin{array}{l}\text { Cultural } \\
\text { orientation/representation }\end{array}$ & $\begin{array}{l}\text { Cultural content } \\
\text { characteristics } \\
\text { (aim/objectives, } \\
\text { activities/tasks, } \\
\text { suitability) }\end{array}$ & $\begin{array}{l}\text { Intercultural } \\
\text { issues/values }\end{array}$ & $\begin{array}{l}\text { Overall } \\
\text { appraisal } \\
\text { of the } \\
\text { textbooks }\end{array}$ \\
\hline 6th & Rationale and Objectives & $0.855^{*}$ & $0.585^{*}$ & $0.554^{*}$ & $0.381^{*}$ & $0.517^{*}$ \\
\hline \multirow[t]{4}{*}{ grade } & $\begin{array}{l}\text { Cultural } \\
\text { orientation/representation }\end{array}$ & $0.687^{*}$ & $0.865^{*}$ & $0.644^{*}$ & $0.507^{*}$ & $0.622^{*}$ \\
\hline & $\begin{array}{l}\text { Cultural content } \\
\text { characteristics } \\
\text { (aim/objectives, } \\
\text { activities/tasks, suitability) }\end{array}$ & $0.711^{*}$ & $0.683^{*}$ & $0.865^{*}$ & $0.489^{*}$ & $0.725^{*}$ \\
\hline & Intercultural issues/values & $0.410^{*}$ & $0.456^{*}$ & $0.489^{*}$ & $0.941^{*}$ & $0.353^{*}$ \\
\hline & $\begin{array}{l}\text { Overall appraisal of the } \\
\text { textbooks }\end{array}$ & $0.570^{*}$ & $0.532^{*}$ & $0.657^{*}$ & $0.324^{*}$ & $0.912^{*}$ \\
\hline
\end{tabular}

\section{Discussion}

\subsection{Reflecting on $R Q 1$}

As already stressed, the acquisition of ICC-skills entails giving more prominence to the small ' $c$ ' dimension in order to fully appreciate the socio-linguistic and socio-cultural implications of language (CEFR, 2001). Moreover, this paradigm is deemed as pedagogically more appropriate for enabling learners to communicate in everyday situations and become interculturally-competent speakers (Wintergerst \& Meveigh, 2010). Nevertheless, as documented, the cultural content in the textbooks was found of rather limited small ' $c$ ' range, thus rendering the importance accorded to small ' $c$ ' culture manifestation either inadequate and hard to exploit as in $\mathrm{B} 1$ or negligible as in $\mathrm{B} 2$.

Accordingly, the cultural input is of primarily knowledge-oriented nature owing to the outperforming Big ' $\mathrm{C}$ ' culture-themes, which together with the noticeable inconsistency regarding the distribution of the three culture categories can be held accountable for insufficiency or even inappropriacy to promote the learners' CA and flourish their ICC (Ashrafi \& Ajideh, 2018). This fact reveals that the cultural content selection did not receive 
due attention when the textbooks were designed and structurally organized ( $\mathrm{Wu}, 2010)$. Consequently, the cultural portrayal in both textbooks cannot actively engage learners in critical cultural reflection (Shin, Eslami, \& Chen, 2011) on the differences between their own culture and other target cultures, thereby failing to instill global cultural consciousness and intercultural citizenship (Byram, 2011).

\subsection{Reflecting on $R Q 2$}

By the same token, scant attention to cultural aspects is observable throughout the textbooks especially in view of C3 references, thus not providing students with opportunities for deep (inter)cultural understanding, cross-cultural comparison and awareness (Ashrafi \& Ajideh, 2018). Based on the content analysis findings B1 appears more interculturally-balanced in terms of topics, given the higher small ' $c$ ' culture frequency and coverage of cultural diversity compared to B2. Yet, according to the e-questionnaire data and the interviews this advantage can hardly be capitalized considering its fiercely articulated defects.

Generally speaking, the cultural input in both textbooks focuses on sterile provision of cultural facts to memorize (Lee, 2009), instead of featuring a variety of cultures and developing the knowledge, skills and attitudes that can pave the way to ICC and optimize the language learning outcomes (Gomez-Rodriguez, 2015; Sercu, 2010). In this regard, it cannot serve as a springboard for the learners to explore the cultural mélange or to prompt a transformative experience that surfaces their insider understandings and facilitates their departure from the cultural border-zone/territory (Byram, 1989; Shaules, 2007). This implies that learners are confined to the role of a passive observer, outsider and passive recipient of information instead of being empowered to interpret cultural phenomena at the level of 'deep culture' (Davcheva, 2008) and express personal meanings by means of making connections and associations with their own culture (Kramsch, 1993).

More simply stated, both textbooks offer 'consumer-tourist competence' (Byram, 1991), showcasing 'culture' from a congratulatory or tourist viewpoint rather than getting under its skin by modifying the learners' existing schemata to accommodate new schemata, experiences and perceptions (Prodromou \& Mishan, 2008). In practice, they incorporate tourism-oriented situations lacking problematic (Skopinskaja, 2003) since anecdotal facts-processing takes precedence over the inculcation of the ICC-constructs.

\subsection{Reflecting on $R Q 3$}

Regarding RQ3, despite their admittedly positive predisposition and struggling efforts towards implementing (inter)cultural teaching, the survey-respondents vigorously expressed their concerns about the time allocated for 'culture teaching' as well as the palpable lack of engaging, up-to-date and authentic cultural-content in the prescribed textbooks. Basically, the vast majority of EFL practitioners participating in this study resort to other resources (internet, digital material, etc.), modify tasks and projects or devise their own supplementary materials in a strenuous effort to integrate 'culture' meaningfully into their teaching practices and equip learners with intercultural knowledge and skills.

Bearing in mind that the targeted textbooks are not identified as culturally-responsive to the challenges they are supposed to meet, 'culture teaching' is contingent upon the EFL teachers' discretion and social responsibility (Byram, 2011) to make sound pedagogical decisions and choices so as to ameliorate and reinforce intercultural instruction. This assumption verifies the claim that cultural meanings are not locked into the materials; instead, "they are created through an interaction between the materials, the learners and the teachers" (Kiss \& Weninger, 2017, pp. 193-194), which explains why the EFL-teachers cannot remain neutral on cultural issues (Byram, Gribkova, \& Starkeym, 2002). In this strand, they are supposed to act as facilitators creating the conditions for the learners' meaningful cultural explorations, whereby the latter have a capacity for change, are alert to alternatives, sensitive to difference and open to experiment (Clarke \& Collins, 2007).

Distinctly, EFL teachers, perceived as culture intermediaries (Shirvan \& Taherian, 2015), cannot rely on the textbooks under evaluation for 'culture teaching'. This proposition justifies their expressed desire for the textbooks' total replacement or re-writing so as to incorporate a well-structured and principled thematic organization along with up-to-date, innovative, authentic and purposeful cultural input suitable for accomplishing the intercultural goals.

\section{Concluding Remarks}

As proclaimed, the study aimed at enlightening the extent to which the EFL textbooks employed in the 5th and 6th grade of the Greek primary school strengthen and upgrade the quality of 'culture teaching' by raising the students' CA and developing their ICC. To this end, the EFL teachers using the particular textbooks were actively involved in almost every phase of the TE process. As it became evident, the research results emphatically depict the teachers' perceptions on the issues explored and provide an insightful picture of the 
'cultural' deficiencies existent in both textbooks, thus practically pinpointing their conspicuous inappropriacy to facilitate and foster dynamic intercultural instruction.

Accordingly, taking for granted the state EFL teachers' strongly substantiated contribution to intercultural education, the need for them to receive formal input in the form of intercultural pre-service and in-service training on how to teach 'culture' is certainly accentuated (Tzotzou \& Kotsiou, 2015). In this way, their professional confidence and empowerment will be boosted as they can become more interculturally-responsive and competent themselves as well as adequately educated to effectively raise the learners' CA and build their own ICC by employing a variety of methods and techniques (Dai, 2011; Karras, 2021). Most importantly, they will be calibrated to meet the challenges involved in embracing an intercultural orientation and enabled to compensate for any shortcomings the existing curricula, syllabi or course books may have. Arguably, it would be pedagogically advisable and constructive that the teachers' opinions and recommendations be recorded, analyzed and seriously taken into consideration by policy makers and courseware authors.

As a corollary, if/when new EFL-textbooks are designed, a primary aim should be to promote CA and encompass the main ICC components in order to accommodate the global purposes of English as EIL (Weber, Aitken, Lupart, \& Scott, 2009). Undoubtedly, this is a challenge that merits proper attention considering the overwhelming changes taking place worldwide and it certainly entails a responsibility towards the young generation of prospective global citizens.

\section{References}

Abolghasem, S. H. F. (2010). Culture assisted language learning (CALL) and teaching general English (pp. 371-376). Paper presented at EABR \& ETLC Conference: Dublin, Ireland.

Abrams, Z. I. (2002). Surfing to Cross-cultural Awareness: Using Internet-Mediated Projects to Explore Cultural Stereotypes. Foreign Language Annals, 35(2),141-157. https://doi.org/10.1111/j.1944-9720.2002.tb03151.x

Ahmed, S. T. S., Quasem, B. T. A., \& Pawar, S. V. (2019). Integrating Culture into EFL Teaching: A Study of Yemeni EFL Teachers' Perceptions and Actual Practices. Language in India, 19(4), 333-348. Retrieved March 23, 2020, from https://www.academia.edu/38722878/Integrating_Culture_into_EFL_Teaching_A_Study_of_Yemeni_EFL_ Teachers_Perceptions_and_Actual_Practices

Ajideh, P., \& Panahi, M. (2016). An analysis of culture-related content in English textbooks for Iranian students entitled 'Prospect' and 'Vision' series. International Journal of Language and Linguistics, 3(6), 87-93.

Al-Sofi, B. B. M. (2018). An Evaluation of the Cultural Aspects in the University English Textbook. Well Read 1. Theory and Practice in Language Studies, 8(2), 184-196. https://doi.org/10.17507/tpls.0802.02

Aliakbari, M. (2004). The Place of Culture in the Iranian ELT textbooks in High School Level (pp. 1-14). Proceedings of the 9th Conference of Pan-Pacific Association of Applied language and Linguistics. Seoul, Korea.

Aliakbari, M., \& Jamalvandi, B. (2013). Realization of culture in English textbooks in Chinese high school level. Journal of Pan-Pacific Association of Applied Linguistics, 16(2), 89-101.

Alptekin, C. (1993). Target-language culture in EFL materials. ELT Journal, 47, 136-143. https://doi.org/10.1093/elt/47.2.136

Anastasiadou, A. (2015). EFL Curriculum Design: The Case of the Greek State Reality in the Last Two Decades (1997-2014). International Journal of Applied Linguistics \& English Literature, 4(2), 112-118. https://doi.org/10.7575/aiac.ijalel.v.4n.2p.112

Ashrafi, S., \& Ajideh, P. (2018). Exploring Culture-related Content in English Textbooks: A Closer Look at Advanced Series of Iran Language Institute. The Journal of Applied Linguistics and Applied Literature: Dynamics and Advances, 6(1), 91-109.

Atai, M. R., Babaii, E., \& Bazargani, D. T. (2017). Developing a Questionnaire for Assessing Iranian EFL Teachers' Critical Cultural awareness. Journal of Teaching Language Skills, 36(2), 1-38.

Bahrami, N. (2015). Evaluating the Representation of Cultural Elements in an In-use EFL Textbook. Advances in Language and Literary Studies, 6(3), 128-137. https://doi.org/10.7575/aiac.alls.v.6n.3p.128

Baker, W. (2012). From cultural awareness to intercultural awareness: Culture in ELT. ELT Journal, 66(1), 62-70. https://doi.org/10.1093/elt/ccr017

Bennet, J. M. (1993). How not to be a Fluent Fool: Understanding the cultural dimension of language. The 
Language Teacher, 27(9), 16-21.

Bernat, E., \& Gvozdenko, I. (2005). Beliefs about Language Learning: Current Knowledge, Pedagogical Implications, and New Research Directions. TESL-EJ, 9, 1-21.

Bhabha, H. K. (1997). Editor's Introduction: Minority Manoeuvres and Unsettled Negotiations. Critical Inquiry, 23(3), 431-439. https://doi.org/10.1086/448837

Bocu, B. A., \& Razi, S. (2016). Evaluation of textbook series 'Life' in terms of cultural components. Journal of Language and Linguistic Studies, 12(2), 221-237.

Bouslama, A., \& Benaissi, F. B. (2018). Intercultural Competence in ELT Contexts: A Study of ELF Teachers' Perceptions. Arab World English Journal (AWEJ), 9(4), 122-135. https://doi.org/10.24093/awej/vol9no4.8

Bradbury, M. (n.d.). Wind and Fly LTD. Retrieved May 19, 2020, from https://www.azquotes.com/citation/quote/595865

Brown, H. D. (2000). Principles of language learning and teaching (4th ed.). New York: Longman.

Bryman, A. (2004). Social Research Methods (2nd ed.). Oxford: Oxford University Press.

Buttjes, D. (1990). Teaching foreign language and culture: Social impact and political significance. Language learning Journal, 2, 53-57. https://doi.org/10.1080/09571739085200471

Byram, M. (1988). Foreign language education and cultural studies. Language, Culture and Curriculum, 1(1), 15-31. https://doi.org/10.1080/07908318809525025

Byram, M. (1989). Cultural Studies in foreign language education. Clevedon, England: Multilingual Matters.

Byram, M. (1991). Teaching Culture and Language: Towards an Integrated Model. In D. Buttjes \& M. Byram (Eds.), Mediating Languages and Cultures: Towards an Intercultural Theory of Foreign Language Education. Clevedon, Avon, England: Multilingual Matters Ltd.

Byram, M. (1997). Teaching and Assessing Intercultural Communicative Competence. Clevedon, Multilingual Matters.

Byram, M. (2011). Intercultural citizenship from an intercultural perspective. Journal of the NUS Teaching Academy, 1(1), 10-20.

Byram, M., Gribkova, B. \& Starkeym, H. (2002). Developing the Intercultural Dimension in Language Teaching: A practical introduction for teachers. Strasbourg: Council of Europe.

Byram, M., \& Wagner, M. (2018). Making a difference: Language teaching for intercultural and international dialogue. Foreign Language Annals, 51(1), 140-151. https://doi.org/10.1111/flan.12319

Canale, M., \& Swain, M. (1980). Theoretical basis of communication approaches to second language teaching and testing. Applied Linguistics, 1, 1-47. https://doi.org/10.1093/applin/I.1.1

Chao, T. (2011). The hidden curriculum of cultural content in internationally published ELT textbooks: A closer look at New American inside out. The Journal of Asian TEFL, 8(2), 189-120.

Chao, T. (2013). Intercultural Learning in EFL Education: Reflections and Suggestions. Selected Papers form the Twenty-second International Symposium on English Teaching.

Chaouche, M. (2016). Incorporating Intercultural Communicative Competence in EFL Classes. Arab World English Journal, 32-42. https://doi.org/10.2139/ssrn.2895538

Chastain, K. (1988). Developing second language skills: Theory and practice (3rd ed.). New York, NY: HBJ Publishers.

Chen, B. B. (2004). A survey on cultural learning and its variables analysis. Xi'an Journal of Xi'an International Studies University, 12(3), 21-24.

Chen, C. M. (2012). The influence of college EFL teachers' understandings of intercultural competence on their self-reported pedagogical practices in Taiwan. English Teaching: Practice and Critique, 11(1), 164-182.

Chen, G. M., \& Starosta, W. J. (2000). The development and validation of the intercultural sensitivity scale. Human Communication, 3, 1-15. https://doi.org/10.1037/t61546-000

Clarke, A., \& Collins, S. (2007). Complexity science and student teacher supervision. Teaching and Teacher Education, 23(2), 160-172. https://doi.org/10.1016/j.tate.2006.10.006

Coelho, P. (2015). Intercultural dialogue. Retrieved February 23, 2020, from 
https://paulocoelhoblog.com/2015/03/13/intercultural-dialogue/

Cohen, L., Manion, L., \& Morrison, K. (2007). Research methods in education (6th ed.). London: Routledge/Falmer. https://doi.org/10.4324/9780203029053

Coombe, C., \& Davidson, P. (2015). Constructing questionnaires. In J. D. Brown \& C. Coombe (Eds.), The Cambridge Guide to Research in Language Teaching and Learning (pp. 217-223). UK: Cambridge University Press.

Cortazzi, M., \& Jin, L. (1999). Cultural mirrors: Materials and methods in the EFL classroom. In E. Hinkel (Ed.), Culture in Second Language Teaching and Learning (pp. 196-219). Cambridge, Cambridge University Press.

Council of Europe. (2001). Common European Framework of References for Languages: learning, teaching assessment. Cambridge: Cambridge University Press.

Creswell, J. W. (2003). Research Design: Qualitative, Quantitative, and mixed Methods Approaches (2nd ed.). Thousand Oaks, CA: Sage.

Cronbach, L. J. (1951). Coefficient alpha and the internal structure of tests. Psychometrika, 16(3), 297-334. https://doi.org/10.4324/9780203029053

Cross-Thematic Curriculum Framework for Modern Foreign Languages. (2003). Government Gazette (Issue B, No 303/13-03-03). Athens: Pedagogical Institution.

Crozet, C., \& Liddicoat, A. J. (1999). The challenge of intercultural language teaching: Engaging with culture in the classroom. In J. Lo Bianco, A. J. Liddicoat \& C. Crozet (Eds.), Striving for the Third Place: Intercultural Competence Through Language Education (pp. 113-126). Canberra: Language Australia.

Cunningsworth, A. (1995). Choosing your Coursebook. Oxford: Heinemann.

Dai, L. (2011). Practical techniques for cultural-based language teaching in the EFL classroom. Journal of Language Teaching and Research, 2(5), 1031-1036. https://doi.org/10.4304/jltr.2.5.1031-1036

Damen, L. (1987). Culture Learning: The fifth dimension in the language classroom. Reading, Mass: Addison-Wesley.

Davcheva, L. (2008). Cultural Content in TEFL. In R. Fay (Ed.), Intercultural Approaches to the Teaching of English (vol. 2, pp. 21-100). Patras: HOU.

Davies, L. (2006). Global citizenship: Abstraction or framework for action? Educational Review, 58(1), 5-25. https://doi.org/10.1080/00131910500352523

Deardorff, D. K. (2006). The identification and assessment of intercultural competence as a student outcome of internationalization at institutions of higher education in the United States. Journal of Studies in International Education, 10(3), 241-266. https://doi.org/10.1177/1028315306287002

Díaz, A. (2013). Intercultural understanding and professional learning through critical engagement. Babel, 48(1), $12-19$.

Duenas, M. (1996). Business English Books and Intercultural Communication Training. Paper presented at the 5th International NELLE/APIA Conference, Languages Through Culture - Culture Through Languages: Intercultural Learning and Awareness Teaching/Training in English and Other European Languages (Zaragoza, Spain, September 1996).

Dweik, B. S. (2007). The role of culture in EFL textbooks. ATEL, 16, 20-26.

Eken, D. T. (2015). Intercultural Communicative Competence: EFL Teachers' Beliefs and Practices. Journal of Teaching and Education, 4(3), 63-71.

Fageeh, A. (2011). At crossroads of EFL learning and culture: How to enhance cross-cultural awareness in EFL college students. Cross-cultural Communication, 7(1), 62-72.

Fantini, A. E. (2000). A central concern: Developing intercultural competence (pp. 26-27). In SIT Occasional Paper Series. Brattleboro (VT).

Fantini, A. E., \& Tirmizi, A. (2006). Exploring and assessing intercultural competence. World Learning Publications. $\quad$ Retrieved March 24, 2020, from https://digitalcollections.sit.edu/cgi/viewcontent.cgi?article=1001\&context=worldlearning_publications

Fay, R. (2008). The Cultural and Intercultural Landscape. In R. Fay (Ed.), Intercultural Approaches to the 
Teaching of English (vol. 1, pp. 49-80). Patras: HOU.

Gogonas, N. (2010). Bilingualism and Multilingualism in Greek Education: Investigating Ethnic Language Maintenance among Pupils of Albanian and Egyptian Origin in Athens. Cambridge Scholars Publishing.

Gomez Rodriguez, L. F. (2015). The Cultural Content in EFL Textbooks and What Teachers Need to Do About it. PROFILE, 17(2), 167-187. https://doi.org/10.15446/profile.v17n2.44272

Gray, J. (2000). The ELT coursebook as cultural artifact: How teachers' sensor and adapt. ELT Journal, 54(3), 274-283. https://doi.org/10.1093/elt/54.3.274

Hall, E. T. (1976). Beyond culture. New York, NY: Doubleday.

Hatoss, A. (2004). A model for evaluating textbooks. Babel, 39(2), 25-32.

Heyvaert, M., Maes, B., \& Onghena, P. (2011). Applying mixed methods research at the synthesis level: An overview. Research in the Schools, 18(1), 12-24. Retrieved April 16, 2020, from https://www.researchgate.net/publication/260115162_Applying_mixed_methods_research_at_the_synthesis _level_An_overview

Jenkins, J. (2003). World Englishes: A Resource Book for Students. London, Routledge.

Jiang, B. (2016). A Study on Textbook Evaluation Criteria for the Teaching of Culture in English Language Teaching. US-China Foreign Language, 14(11), 790-794. https://doi.org/10.17265/1539-8080/2016.11.007

Jiang, W. (2000). The relationship between culture and language. ELT Journal, 54(4), 328-334. https://doi.org/10.1093/elt/54.4.328

Kachru, B. B. (1985). Standards, codifications and sociolinguistic realism: The English language in the outer circle. In R. Quirk \& H. Widdowson (Eds.), English in the world: teaching and learning the language and literatures. Cambridge: Cambridge University Press.

Kachru, B. B. (2004). Asian Englishes: Beyond the Canon. Hong Kong: Hong Kong University Press.

Kachru, Y., \& Smith, L. (2008). Culture, contexts and world Englishes. London: Routledge. https://doi.org/10.4324/9780203891346

Kailola, T. W. (2016). Intercultural exposure in English in Mind Students Book 3. Master's Thesis. Retrieved March 20, 2020, from https://www.semanticscholar.org/paper/Intercultural-exposureinEnglishinMindStudentsKailola/cc7c3b1f63c 2f26003e38702c1a5e70953e2e81d

Karavas, K. (2004). The Evaluation of Courses, Textbooks and Tasks. In C. Ayakli \& K. Karavas (Eds.), Course Design and Evaluation (Vol. 2, pp. 149-246). Patras: HOU.

Karras, I. (2018). Intercultural Approaches in the Foreign Language Classroom. In E. Griva \& V. Zorbas (Eds.), Multicultural and Citizenship Awareness Through Language: Cross Thematic Practices in Language Pedagogy (pp. 3-24). New York: Nova Science Publishers.

Karras, I. (2021). Raising Intercultural Awareness in Teaching Young Learners in EFL Classes. Research Papers in Language Teaching and Learning, 11(1), 173-184.

Kiss, T., \& Weninger, C. (2013). Exploring cultural potential in EFL textbooks: Fostering cultural reflexivity in the classroom. Malaysian Journal of ELT Research, 9(1), 19-28.

Kiss, T., \& Weninger, C. (2017). Cultural learning in the EFL classroom: the roles of visuals. ELT Journal, 71(2), 186-196. https://doi.org/10.1093/elt/ccw072

Klotz, J. H. (2006). A computational Approach to Statistics. Retrieved May 26, 2020, from http://www.stat.wisc.edu/ klotz/Book.pdf

Koroglu, Z. C. (2016). An Investigation on Intercultural Communicative Competence's Integration into Textbooks; Language Instructors' Perspectives. Cilt, 24(2), 619-632.

Kramsch, C. (1987). Foreign language textbooks' construction of foreign reality. The Canadian Modern Language Review, 44(1), 95-119. https://doi.org/10.3138/cmlr.44.1.95

Kramsch, C. (1993). Context and Culture in Language Teaching. Oxford, England: Oxford University Press.

Kramsch, C. (2002). Language Acquisition and Language Socialization: Ecological Perspectives. London: Continuum. 
Kreisberg, S. (1992). Transforming power. Albany: State University of New York Press.

Krippendorff, K. (2004). Content Analysis: An Introduction to its Methodology (2nd ed.). Thousand Oaks, CA: Sage Publications.

Kumaravadivelou, B. (2008). Cultural Globalization and Language Education. New Haven and London, CT: Yale University Press.

Larzen, E. (2005). In pursuit of an intercultural dimension in EFL-teaching: Exploring cognitions among Finland-Swedish comprehensive school teachers. Abo: Abo Akademi University Press.

Lee, K.-Y. (2009). Treating culture: What 11 high school EFL conversation textbooks in South Korea Do. English Teaching: Practice and Critique, 8, 76-96.

Lee, K.-Y. (2012). Teaching intercultural English learning/teaching in World Englishes: Some classroom activities in South Korea. English Teaching: Practice and Critique, 11(4), 190-205.

Littlejohn, A. (2011). The analysis of language teaching materials: Inside the Trojan Horse. In B. Tomlinson (Ed.), Materials development in language teaching (2nd ed., pp. 179-211). Cambridge, UK: Cambridge University Press.

Litz, D. R. A. (2005). Textbook evaluation and ELT Management: A South Korean Case Study. Asian EFL Journal. Retrieved March 10, 2020, from https://www.asian-efl-journal.com/Litz_thesis.pdf

Liu, K. (2016). Prioritizing Criteria for Evaluating Cultural contents in EFL Textbooks through AHP. Journal of Language Teaching and Research, 7(5), 841-850. https://doi.org/10.17507/jltr.0705.03

Liu, K. (2019). The nexus of language and culture: A review of literature on intercultural communicative competence in foreign language education. Cambridge Open-Review Educational Research e-Journal, 6, $50-65$.

Lo Bianco, J., Liddicoat, A. J., \& Crozet, C. (Eds.). (1999). Striving for the third place: Intercultural competence through language education. Melbourne: Language Australia.

Lytra, V. (2008). Intercultural Space in Multicultural Schools in Greece. In R. Fay et al. (Eds.), Intercultural Approaches to the Teaching of English (vol. 2, pp. 101-166). Patras: HOU.

Masuhara, H., \& Tomlinson, B. (2013). Language acquisition and language learning materials. In B. Tomlinson (Ed.), English language learning materials; A critical review (pp. 18-37). New York, NY: Continuum.

Mayangsari, L., Nurkamto, J., \& Supriyadi, S. (2018). Cultural content: An analysis of EFL Textbook in Indonesia. International Journal of Scientific and Research Publications, 8(11), 192-199. https://doi.org/10.29322/IJSRP.8.11.2018.p8325

McGrath, I. (2002). Materials Evaluation and design for language Teaching. Edinburgh University Press.

McKay, L. S. (2003). Toward an appropriate EIL pedagogy: Re-examining common ELT assumptions. International Journal of Applied Linguistics, 13(1), 1-22. https://doi.org/10.1111/1473-4192.00035

Mekheimer, M. A. (2011). Impact of the target culture on foreign language learning: A case study. Cross-cultural Communication, 7(1), 43-52.

Mendez Garcia, M. C. (2005). International and intercultural issues in English teaching textbooks: The case of Spain. Intercultural Education, 16(1), 57-68. https://doi.org/10.1080/14636310500061831

Moje, E., McIntosh Ciechanowski, K., Kramer, K., \& Ellis, L. (2004). Working towards third space in content area literacy: An examination of everyday funds of knowledge and Discourse. Reading Research Quarterly, 39(1), 38-70. https://doi.org/10.1598/RRQ.39.1.4

Moran, P. R. (2001). Teaching culture: Perspectives in Practice. Boston, Mass: Heinle and Heinle.

Morgan, C. (1995). Cultural awareness and the National Curriculum. Language Learning Journal, 12, 9-12. https://doi.org/10.1080/09571739585200331

Nault, D. (2006). Going global: Rethinking culture teaching in ELT contexts. Language, Culture and Curriculum, 19(3), 314-328. https://doi.org/10.1080/07908310608668770

Nguyen, M. T. T. (2011). Learning to communicate in a globalized world: To what extent do school textbooks facilitate the development of intercultural pragmatic competence? RELC Journal, 42(1), 17-30. https://doi.org/10.1177/0033688210390265

Nunan, D. (1991). Communicative tasks and the language curriculum. TESOL Quarterly, 25(2), 279-296. 
https://doi.org/10.2307/3587464

Paige, R. M., Jorstad, H., Paulson L., Klein, F., \& Colby, J. (1999). Culture learning in language education: A Review of the Literature. In R. M. Paige, D. L. Lange \& Y. A. Yershova (Eds.), Culture as the Core: Integrating Culture into the Language Curriculum (pp. 47-113). Minneapolis, MN: University of Minnesota.

Patton, M. Q. (2002). Qualitative research and evaluation methods (3rd ed.). Thousand Oaks, CA: Sage.

Peck, D. (1998). Teaching Culture: Beyond Language. Yale: New Haven Teachers Institute.

Penderi, E. (2018). Theoretical and practical issues concerning young children's citizenship education: The program "Learn, Care and Act about my city". Journal of Education and Training, 5(2), 141-164. https://doi.org/10.5296/jet.v5i2.13038

Pennycook, A. (1994). The Cultural Politics of English as an International Language. London, Longman.

Pennycook, A. (2007). Global Englishes and transcultural flows. London, England: Routledge. https://doi.org/10.4324/9780203088807

Prodromou, L., \& Mishan, F. (2008). Materials used in Western Europe. In B. Tomlinson (Ed.), English Language Teaching Materials: A Critical Review (pp. 193-212). London: Continuum.

Raigon-Rodriguez, A. (2018). Analysing cultural aspects in EFL textbooks: A skill-based analysis. Journal of English Studies, 16, 281-300. https://doi.org/10.18172/jes.3478

Reimann, A. (2009). A Critical analysis of cultural content in EFL materials. Utsunomiya University Faculty of International Studies, 28, 85-101.

Richards, K. (2003). Qualitative Inquiry in Research. New York, NY: Palgrave, Macmillan. https://doi.org/10.1057/9780230505056

Risager, K. (1991). Cultural references in European foreign language textbooks: An evaluation of recent tendencies. In D. Buttjes \& M. Byram (Eds.), Mediating languages and cultures: Towards an intercultural theory of foreign language education (pp. 181-192). Clevedon: Multilingual Matters.

Robinett, B. W. (1980). Teaching English to speakers of other languages: Substance and technique. Minneapolis: university of Minesota Press. (JSTOR).

Robinson, G. L. N. (1985, 1988). Cross cultural Understanding. London, Pergamon (Prentice Hall).

Robson, C. (2007). How to Do a Research Project: A Guide for Undergraduate Students. Oxford, Blackwell Publishing.

Sandarova, Z. (2014). Content Analysis as a Research Method in Investigating the Cultural Components in Foreign Language Textbooks. Journal of Language and cultural Education, 2(1), 95-128.

Sandelowski, M. (2000). Focus on Research Methods: Combining Qualitative and Quantitative Sampling, Data Collection, and Analysis Techniques in Mixed-Method Studies. Research in Nursing \& Health, 23, 246-255. https://doi.org/10.1002/1098-240X(200006)23:3<246::AID-NUR9>3.0.CO;2-H

Seelye, H. N. (ed.) (1993). Teaching Culture: Strategies for Intercultural Communication (3rd ed.). Lincolnwood, ILL: National Textbook Company.

Sellami, A. B. (2000). Teaching towards cultural awareness and cultural competence: From What through How to Why culture is? Paper presented at the Annual Teachers of English to Speakers of Other Languages.

Sercu, L. (1998). In-service teacher training and the acquisition of intercultural competence. In Byram \& M. Flemming (Eds.), Language learning in intercultural perspective: Approaches through drama and ethnography. Cambridge: Cambridge University Press.

Sercu, L. (2002). Autonomous Learning and the Acquisition of Intercultural Communicative Competence: some implications for Course Development. Language, Culture and Curriculum, 15(1), 61-74, Multilingual Matters. https://doi.org/10.1080/07908310208666633

Sercu, L. (2010). 'Assessing Intercultural Competence: More Questions than Answers. In A. Paran \& L. Sercu (Eds.), Testing the Untestable in Language Education. UK, USA, Canada, Multilingual Matters. https://doi.org/10.21832/9781847692672-004

Shaules, J. (2007). Deep Culture - The Hidden Challenges of Global Living. Clevedon, Multilingual Matters. https://doi.org/10.21832/9781847690180 
Sheldon, L. (1988). Evaluating ELT textbooks and materials. ELT Journal, 42(4), 237-246. https://doi.org/10.1093/elt/42.4.237

Shin, J., Eslami, Z., \& Chen, W. (2011). Presentation of local and international culture in current international English-language teaching textbooks. Language, Culture, and Curriculum, 24, 253-268. https://doi.org/10.1080/07908318.2011.614694

Shirvan, M. E., \& Taherian, T. (2015). On the Ecological Evaluation of Iranian Secondary Schools English Course Books in Light Intercultural Communicative Competence: Knowledge, Skills, and Attitude. Sino-US English Teaching, 12(12), 891-905. https://doi.org/10.17265/1539-8072/2015.12.001

Sifakis, N. (2009). Challenges in teaching ELF in the periphery: The Greek context. ELT Journal, 63(3), 230-237. https://doi.org/10.1093/elt/ccn057

Sifakis, N. (2014). Teaching pronunciation in the post-EIL era: lessons from ELF and implications for teacher education. In H. Agudo (Ed.), English as a foreign Language Teacher Education: Current perspectives and challenges (pp. 127-146). New York: Amsterdam. https://doi.org/10.1163/9789401210485_009

Skopinskaja, L. (2003). The role of culture in foreign language teaching materials: An evaluation from an intercultural perspective. In I. Lazar (Ed.), Incorporative intercultural communicative competence in language teacher education (pp. 39-68).

Tashakkori, A., \& Teddlie, C. (2010). SAGE handbook of mixed methods in social and behavioral research (2nd ed.). Thousand Oaks, CA: Sage. https://doi.org/10.4135/9781506335193

Tavakol, M., \& Dennick, R. (2011). Making Sense of Cronbach's Alpha. International Journal of Medical Education, 2, 53-55. https://doi.org/10.5116/ijme.4dfb.8dfd

Thanasoulas, D. (2001). The importance of teaching culture in the classroom. Racial Pedagogy, 3(3), 1-24.

Tomalin, B. (2008). Culture the fifth skill. British Council. Retrieved March 12, 2020, from https://www.teachingenglish.org.uk/article/culture-fifth-language-skill

Tomalin, B., \& Stempleski, S. (2013). Cultural Awareness. Oxford: Oxford University Press.

Tomlinson, C. A. (2001). How to differentiate instruction in mixed-ability classrooms (2nd ed.). Alexandria, VA: ASCD.

Tylor, E. B. (1871). Primitive Culture: Researches into the Development of Mythology, Philosophy, Religion, Art and Custom. U.K.: Oxford University Press.

Tzotzou, M. D. (2013). A critical analysis and evaluation of the Unified Curriculum for the Foreign Languages (EPS-XG Curriculum). ASPECTS Today, 36, 16-23. Retrieved April 20, 2020, from https://www.researchgate.net/publication/291523101_A_critical_analysis_and_evaluation_of_the_Unified_ Curriculum_for_the_Foreign_Languages_EPS-XG_Curriculum

Tzotzou, M., \& Kotsiou, V. (2015). Exploring the position of target language awareness in the EFL classroom of the Greek state school. Research Papers in Language Teaching and Learning, 6(1), 68-85.

Ur, P. (1996). A Course in Language Teaching: Practice and theory. Cambridge: CUP.

Van Ek, J. (1986). Objectives for Modern Language Teaching. Strasbourg: Council of Europe.

Vernier, S. S., Bartuzza, S. D., Giusti, \& Moral, G. D. (2008). The five language skills in the EFL classroom. Nueva Revista de Lenguas Extranjeras, 10, 263-291.

Wallen, N. E., \& Fraenkel, J. R. (2011). Educational Research: A Guide to the Process (2nd ed.). Taylor \& Francis e-Library.

Webber, C. F., Aitken, E. N., Lupart, J., \& Scott, S. (2009). The Alberta student assessment study final report. Edmonton, AB: Alberta Education.

Widdowson, H. G. (2005). Teaching English as a Global Language. TESOL Teaching in mind, British Council, Tokyo, November 20th, University Press.

Williams, D. (1983). Developing criteria for textbook evaluation. ELT Journal, 37(3), 251-255. https://doi.org/10.1093/elt/37.3.251

Wintergerst, A. C., \& McVeigh, J. (2010). Tips for teaching culture: A practical approach to intercultural communication. White Plains, NY: Pearson Longman.

Wright, M. (1999). Influences on learner attitudes towards foreign language and culture. Educational Research, 
41(2), 197-208. https://doi.org/10.1080/0013188990410207

$\mathrm{Wu}, \mathrm{J}$. (2010). A content analysis of the cultural content in the EFL textbooks. Canadian Social Science, 6(5), $137-144$.

Xiao, J. (2010). Cultural content of an in use EFL textbook and English major students' attitudes and perceptions towards cultural learning. Jiangxi University of science and Technology, China. Unpublished $\mathrm{PhD}$ thesis, Prince of Songkla University, Thailand.

Yuen, K.-M. (2011). The representation of foreign cultures in English textbooks. ELT Journal: English Language Teaching Journal, 65(4), 458-466. https://doi.org/10.1093/elt/ccq089

Zhang, X. (2017). A critical review of literature on English language teaching textbook evaluation: What systemic functional linguistics can offer. Journal of Language and Cultural Education, 5(1), 78-102. https://doi.org/10.1515/jolace-2017-0005

Zhao, B. (2010). How to enhance cross-cultural awareness in TEFL. Cross-Cultural Communication, 6(2), $100-104$.

$\mathrm{Zu}, \mathrm{L}$., \& Kong, Z. (2009). A study on the approaches to culture introduction in English textbooks. English Language Teaching, 2(1), 112-118. https://doi.org/10.5539/elt.v2n1p112

\section{Acknowledgements}

I would like to express my sincere gratitude to my professor Dr. Ioannis Karras for his insightful feedback, guidance and encouragement throughout the difficult and arduous writing process of this research article.

\section{Disclosure statement}

No potential conflict of interest was reported by the author.

\section{Notes}

Note 1. Cross-curricular/Cross-Thematic curriculum Framework.

Note 2. Integrated Foreign Languages Curriculum.

Note 3. Foreign Language.

Note 4. TEFL promotes the target language and culture (Fay, 2008).

Note 5. Teaching English for Intercultural Communication Paradigm.

Note 6. Teaching English for Multicultural Awareness Paradigm.

Note 7. Native speaking.

Note 8. 'Culture learning' is the process of acquiring culture-specific and culture general (intercultural) knowledge, skills and attitudes required for effective communication (Paige et al., 1999, p. 50).

Note 9. Bahrami (2015), Chen (2012), Jiang (2016), Sercu (1998), Masuhara and Tomlinson (2013), Moran (2001) and Widdowson (2005).

Note 10. The alpha coefficient (a) of 0.70 or higher suggests that the items have relatively high internal consistency, thus it is considered "acceptable" in most social science research situations.

Note 11. $0.5>\mathrm{a}$ indicates unacceptable internal consistency, $0.6>\mathrm{a} \geq 0.5$ poor, $0.7>\mathrm{a} \geq 0.6$ questionable, $0.8>\mathrm{a} \geq 0.7$ acceptable, $0.9>\mathrm{a} \geq 0.8$ good and $\mathrm{a} \geq 0.9$ excellent internal consistency.

\section{Copyrights}

Copyright for this article is retained by the author, with first publication rights granted to the journal.

This is an open-access article distributed under the terms and conditions of the Creative Commons Attribution license (http://creativecommons.org/licenses/by/4.0/). 